\title{
Circulation and Water Mass Modification in the Brazil-Malvinas Confluence
}

\author{
LOIC JULLION AND KAREN J. HeYWOOD \\ School of Environmental Sciences, University of East Anglia, Norwich, United Kingdom \\ Alberto C. Naveira Garabato \\ National Oceanography Centre, Southampton, Southampton, United Kingdom \\ DAVID P. STEVENS \\ School of Mathematics, University of East Anglia, Norwich, United Kingdom
}

(Manuscript received 3 November 2008, in final form 4 November 2009)

\begin{abstract}
The confluence between the Brazil Current and the Malvinas Current [the Brazil-Malvinas Confluence $(\mathrm{BMC})]$ in the Argentine Basin is characterized by a complicated thermohaline structure favoring the exchanges of mass, heat, and salt between the subtropical gyre and the Antarctic Circumpolar Current (ACC). Analysis of thermohaline properties of hydrographic sections in the BMC reveals strong interactions between the ACC and subtropical fronts. In the Subantarctic Front, Subantarctic Mode Water (SAMW), Antarctic Intermediate Water (AAIW), and Circumpolar Deep Water (CDW) warm (become saltier) by $0.4^{\circ}(0.08)$, $0.3^{\circ}(0.02)$, and $0.6^{\circ} \mathrm{C}(0.1)$, respectively. In the subtropical gyre, AAIW and North Atlantic Deep Water have cooled (freshened) by $0.4^{\circ}(0.07)$ and $0.7^{\circ} \mathrm{C}(0.11)$, respectively.

To quantify those ACC-subtropical gyre interactions, a box inverse model surrounding the confluence is built. The model diagnoses a subduction of $16 \pm 4 \mathrm{~Sv}\left(1 \mathrm{~Sv} \equiv 10^{6} \mathrm{~m}^{3} \mathrm{~s}^{-1}\right)$ of newly formed SAMW and AAIW under the subtropical gyre corresponding to about half of the total subduction rate of the South Atlantic found in previous studies. Cross-frontal heat $(0.06 \mathrm{PW})$ and salt $\left(2.4 \times 10^{12} \mathrm{~kg} \mathrm{~s}^{-1}\right)$ gains by the ACC in the BMC contribute to the meridional poleward heat and salt fluxes across the ACC. These estimates correspond to perhaps half of the total cross-ACC poleward heat flux. The authors' results highlight the BMC as a key region in the subtropical-ACC exchanges.
\end{abstract}

\section{Introduction}

The Brazil-Malvinas Confluence (BMC) is a region of transition between the Brazil Current (BC), the southwardflowing western boundary current of the South Atlantic subtropical gyre, and the Malvinas Current (MC), a northward-flowing branch of the Antarctic Circumpolar Current (ACC; Gordon 1989). The BMC is believed to be a prominent site for the exchange of water masses, heat, and freshwater between the subtropical ocean and the ACC. Assessing the exchanges is important for two reasons: 1) to obtain a better understanding of the southern limb of the Atlantic meridional overturning circu-

Corresponding author address: Loic Jullion, National Oceanography Centre, Southampton, Ocean Observing and Climate, European Way, S014 3ZH Southampton, United Kingdom.

E-mail: 1.jullion@noc.soton.ac.uk lation and 2) to gain insight into the way in which heat and salt uptake at the ACC's northern rim compensate for the net air-sea heat loss and net precipitation occurring south of $60^{\circ} \mathrm{S}$. Addressing these issues is the goal of this paper.

Previous studies have shown that the $\mathrm{BC}$ at $28^{\circ} \mathrm{S}$ transports $25 \mathrm{~Sv}\left(1 \mathrm{~Sv} \equiv 10^{6} \mathrm{~m}^{3} \mathrm{~s}^{-1}\right)$ of warm $\left(\theta>10^{\circ} \mathrm{C}\right)$ and salty $(S>35)$ South Atlantic Central Water (SACW) southward in a well-defined boundary current tightly constrained against the continental slope. East of the BC, a weak Deep Western Boundary Current (DWBC) conveys 2.8 Sv of North Atlantic Deep Water (NADW; Müller et al. 1998) southward. The MC transports northward cold $\left(\theta<7^{\circ} \mathrm{C}\right)$ and fresh $(S<34.3)$ water of largely subantarctic origin. The transport of the $\mathrm{MC}$ along the Patagonian continental slope has been estimated from current meters to be $30.8 \pm 6 \mathrm{~Sv}$ in 1993-95 (Vivier and Provost 1999) and 33.3 $\pm 7 \mathrm{~Sv}$ in 2001-03 (Spadone and 
Provost 2009), with significant annual and semiannual variations.

The mean position of the BMC is located near $38^{\circ} \mathrm{S}$ but varies with season (Olson et al. 1988; Garzoli and Garaffo 1989). The driving processes for this seasonal variability remain unclear. Modeling studies suggest that the variability of the BMC position is partially influenced by variations in the MC transport, itself linked to fluctuations in the ACC transport and in the wind stress over the Southern Ocean (Matano 1993; Wainer et al. 2000; Fetter and Matano 2008). On the other hand, observational studies suggest that the variability of the position of the BMC is forced primarily by the local wind field (Garzoli and Giulivi 1994). The extent to which the meridional translation of the BMC on intraseasonal and longer time scales conditions water mass modification and transport across the confluence is unknown.

The confluence of subantarctic and subtropical waters in the BMC region is organized in a series of zones of relatively homogeneous thermohaline properties separated by four fronts and associated jets (from south to north): the Polar Front (PF), the Subantarctic Front (SAF), the Subtropical Front (STF), and the Brazil Current Front (BCF). The close proximity of these fronts facilitates crossfrontal mixing between subantarctic and subtropical waters, as evidenced by the complex thermohaline vertical and horizontal structure of the region (Reid et al. 1977; Gordon 1989; Maamaatuaiahutapu et al. 1992; Bianchi et al. 1993; Provost et al. 1996; Bianchi et al. 2001). The $\mathrm{BMC}$ is also characterized by an intense mesoscale eddy activity (Fig. 1a) that has been studied using remote sensing techniques (Olson et al. 1988; Wilson and Rees 2000; Goni and Wainer 2001; Garnier et al. 2003; Saraceno et al. 2004). The presence of a vigorous eddy field and the intricate vertical structure of water masses are believed to be major factors shaping water mass modifications and exchanges of heat and freshwater between the subtropical and subantarctic domains of the BMC (Gordon 1989; Provost et al. 1999; Sun and Watts 2002).

In the BMC, Subantarctic Mode Water (SAMW) and Antarctic Intermediate Water (AAIW), which are formed in the southeast Pacific and Drake Passage (Talley 1996; Naveira Garabato et al. 2009), are subducted under the upper-ocean water masses of the subtropical gyre, thereby cooling, freshening, and ventilating the subtropical thermocline (Tsuchiya et al. 1994). The BMC has been argued to be the subtropical gyre's main ventilation region (Campos et al. 1995), but a quantitative estimate of the cross-stream subduction and mixing of mode and intermediate waters in the BMC is lacking. The mechanisms by which SAMW and AAIW are subducted under the subtropical gyre are also under discussion at present.
Several studies highlight the role of eddy-induced mixing in regulating subduction at the equatorward edge of the ACC (Marshall 1997; Marshall et al. 2006). Marshall (1997) showed that, in regions of intense baroclinic instability such as the BMC, the contribution of eddies to the large-scale subduction of a water mass may be of the same order of magnitude as Eulerian-mean advection. Recently, the eddy-permitting modeling study by Tanaka and Hasumi (2008) proposed a dominant role for eddies in the subduction of newly formed intermediate water in the BMC. Lagrangian observations also suggest that the $\mathrm{BMC}$ is a key region for the transfer of intermediate water masses from the subantarctic to the subtropical regime: Davis et al. (1996) observed two of their Autonomous Lagrangian Circulation Explorer (ALACE) floats deployed north of the PF in Drake Passage being caught in the confluence and subsequently drifting eastward with the subtropical gyre toward the Mid-Atlantic Ridge.

The circulation of the BMC is greatly influenced by the presence of the Zapiola Rise (ZR), a sediment mount that extends zonally along $45^{\circ} \mathrm{S}$ between $36^{\circ}$ and $51^{\circ} \mathrm{W}$. The Zapiola Rise is associated with a strong (around $100 \mathrm{~Sv}$ ) anticyclonic circulation (Saunders and King 1995a) and stands out clearly as a region of low eddy kinetic energy (EKE; Fig. 1a) surrounded by high EKE. Saraceno et al. (2004) also reported that the center of the Zapiola recirculation is a gradient-free region in Advanced Very High Resolution Radiometer (AVHRR) sea surface temperature data and argued that the closed planetary vorticity contour around the rise acts as a boundary isolating the center of the circulation cell from the highly variable BMC. The dynamics of the Zapiola anticyclone have been extensively studied (see, e.g., Dewar 1998; Fu et al. 2001; Fu 2007; Weijer et al. 2008a,b), but its role in water mass modification remains an open question. One can conjecture that its location between the ACC and the subtropical gyre may make it a significant contributor to the water mass exchanges between the subtropical and subantarctic domains of the BMC.

In this paper, the circulation and modification of water masses in the BMC are investigated by analyzing a collection of high-quality hydrographic observations in the area and constructing a regional box inverse model using a subset of those observations. Quantifying the crossfrontal exchanges between subantarctic and subtropical waters, the subduction rate of SAMW and AAIW, and the transports of heat and salt between the ACC and the subtropical gyre are of particular interest to this study. In section 2, evidence of water mass modification in the Argentine Basin (AB) from hydrographic data will be presented. Section 3 will introduce the inverse model. The model's results will be presented and discussed in 

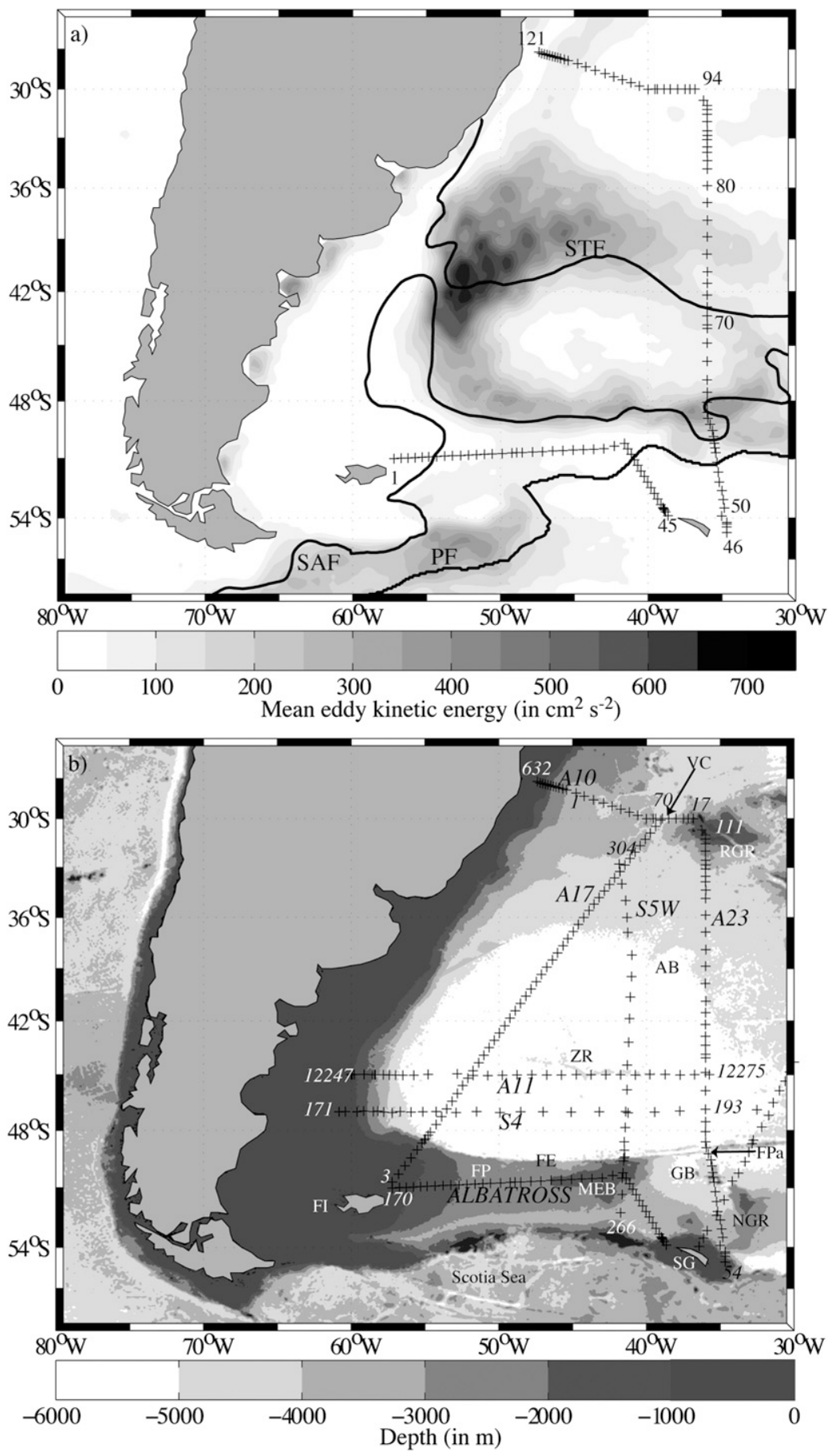

FIG. 1. (a) Mean EKE $\left(\mathrm{cm}^{2} \mathrm{~s}^{-2}\right)$ in the AB calculated from altimetry data. The altimeter products were produced by Segment Sol Multimissions d'Altimétrie, d'Orbitographie et de Localisation Précise/Multimission Altimeter Data Processing System (SSALTO/DUACS) and distributed by Archiving, Validation, and Interpretation of Satellite Oceanographic data (AVISO), with support from Centre National d'Études Spatiales (CNES; available online at http://www.aviso.oceanobs.com/en/ data/products/index.html). The climatological positions of the SAF, PF, and STF are shown (Orsi et al. 1995). (b) Map of the AB showing the sections used in this study (named in italics). The bathymetry (Smith and Sandwell 1997) is also shown in gray (m) and the main topographical features are labeled. Shown are AB, FE, FP, Falkland Passage (FPa), GB, FI, MEB, NGR, RGR, S4, S5, SG, VC, and ZR. 
TABLE 1. Summary of the sections used in this study. The stations used in this paper and papers describing each section are given as an indication.

\begin{tabular}{|c|c|c|c|c|c|}
\hline Cruise & Date & Country & Ship & $\begin{array}{l}\text { Shipboard } \\
\text { station No. }\end{array}$ & $\begin{array}{l}\text { Relevant } \\
\text { paper }\end{array}$ \\
\hline A11 & Dec 1992-Jan 1993 & United Kingdom & RRS Discovery & $12247-12275$ & $\begin{array}{l}\text { Saunders and King } \\
\quad(1995 b)\end{array}$ \\
\hline A17 & Jan-Feb 1994 & France & $\mathrm{R} / \mathrm{V}$ Maurice Ewing & $3-70$ & Memery et al. (2000) \\
\hline A10 & Dec 1992-Jan 1993 & Germany & Meteor & $1-17$ and $622-632$ & Siedler et al. (1996) \\
\hline A 23 & Mar-May 1995 & United Kingdom & RRS J.C. Ross & $\begin{array}{c}54-64,73-82,84 \\
\text { and } 86-111\end{array}$ & $\begin{array}{l}\text { Heywood and King } \\
\text { (2002) }\end{array}$ \\
\hline ALBATROSS & Mar-Apr 1999 & United Kingdom & RRS J. C. Ross & $124-170$ & $\begin{array}{l}\text { Naveira Garabato } \\
\text { et al. (2002) }\end{array}$ \\
\hline S4 & Dec 1988-Jan 1989 & United States & $\mathrm{R} / \mathrm{V}$ Melville & $171-193$ & SIO (1992) \\
\hline S5 & Apr-Jun 1989 & United States & $\mathrm{R} / \mathrm{V}$ Melville & $237-308$ & SIO (1992) \\
\hline
\end{tabular}

section 4, and the main conclusions of this work reviewed in section 5 .

\section{Thermohaline structure of the BMC}

Seven hydrographic sections comprising 303 CTD profiles (Table 1; Fig. 1b) located within and along the rim of the Argentine Basin are used to study the spatial evolution of the thermohaline characteristics of water masses in the BMC. They encompass a $10-\mathrm{yr}$ period from 1989 to 1999 . Figure 2 illustrates the strong contrast between subantarctic $\left(S \sim 33.5 ; \theta \sim 3.5^{\circ} \mathrm{C}\right)$ and subtropical $\left(S \sim 37 ; \theta \sim 25^{\circ} \mathrm{C}\right)$ waters and the sharp fronts separating the different water masses. Here, we focus on the SAMW/AAIW (Figs. 3a-d) and Circumpolar Deep Water (CDW)/NADW (Figs. 4a-d) density classes, where the most significant variability (outside the surface layers) occurs (Fig. 2).

$$
\text { a. } S A M W / A A I W\left(\gamma^{n}=26.6-27.55 \mathrm{~kg} \mathrm{~m}^{-3}\right)
$$

SAMW, characterized by a salinity of 34.13 and a potential temperature of $4.6^{\circ} \mathrm{C}$ on a neutral density $\gamma^{n}$ (Jackett and McDougall 1997) surface of $27.2 \mathrm{~kg} \mathrm{~m}^{-3}$ (Fig. 3a, solid lines), is found within the SAF. Later, AAIW is characterized by a salinity minimum on $\gamma^{n}=$ $27.40 \mathrm{~kg} \mathrm{~m}^{-3}\left(S \approx 34.18 ; \theta \approx 3.0^{\circ} \mathrm{C}\right)$ in the SAF just north of the Falkland Escarpment (FE; Fig. 3a, solid lines). In the SAF retroflection, SAMW and AAIW are warmer $\left(\theta \approx 5^{\circ} \mathrm{C}\right.$ and $\theta \approx 3.3^{\circ} \mathrm{C}$, respectively) and saltier $(S \approx 34.21$ and $S \approx 34.2$, respectively; Fig. 3a, dashed lines) than waters of the same density in the northward-flowing SAF. Over the Falkland Plateau (FP) and in the Georgia Basin

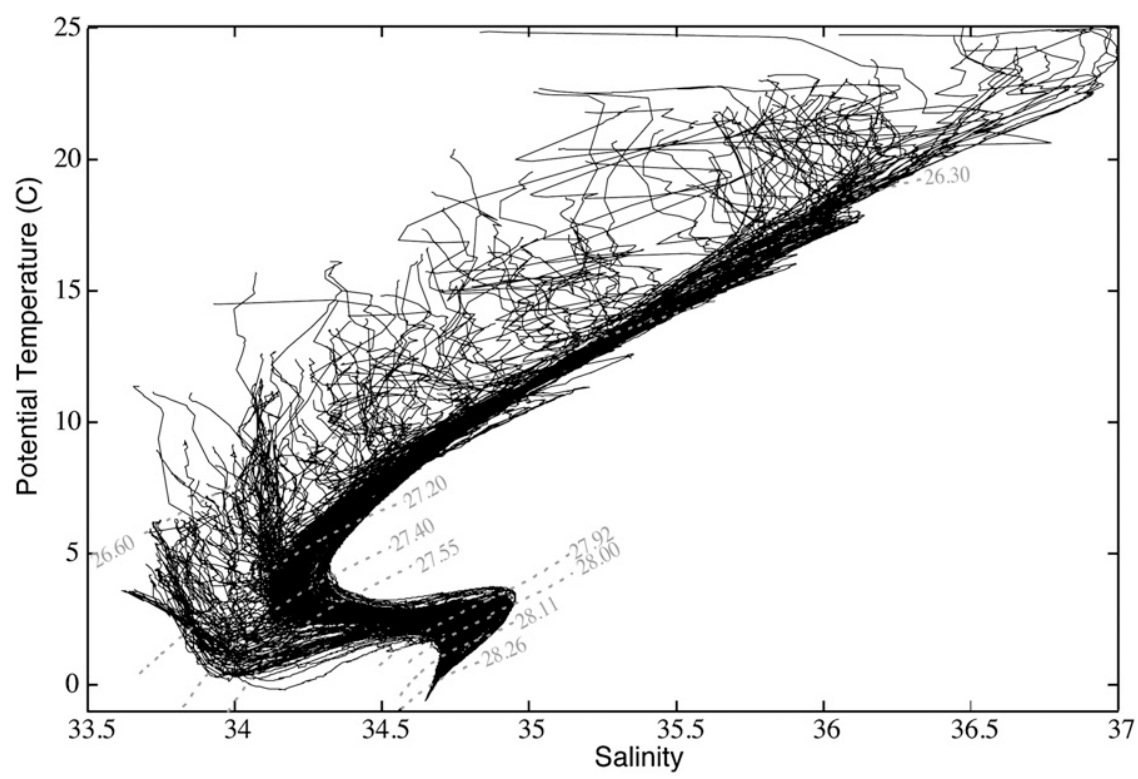

FIG. 2. Thermohaline properties of all the stations located in the AB used in this study (Fig. 1). The gray dashed lines are the neutral density boundaries of the main water masses. 

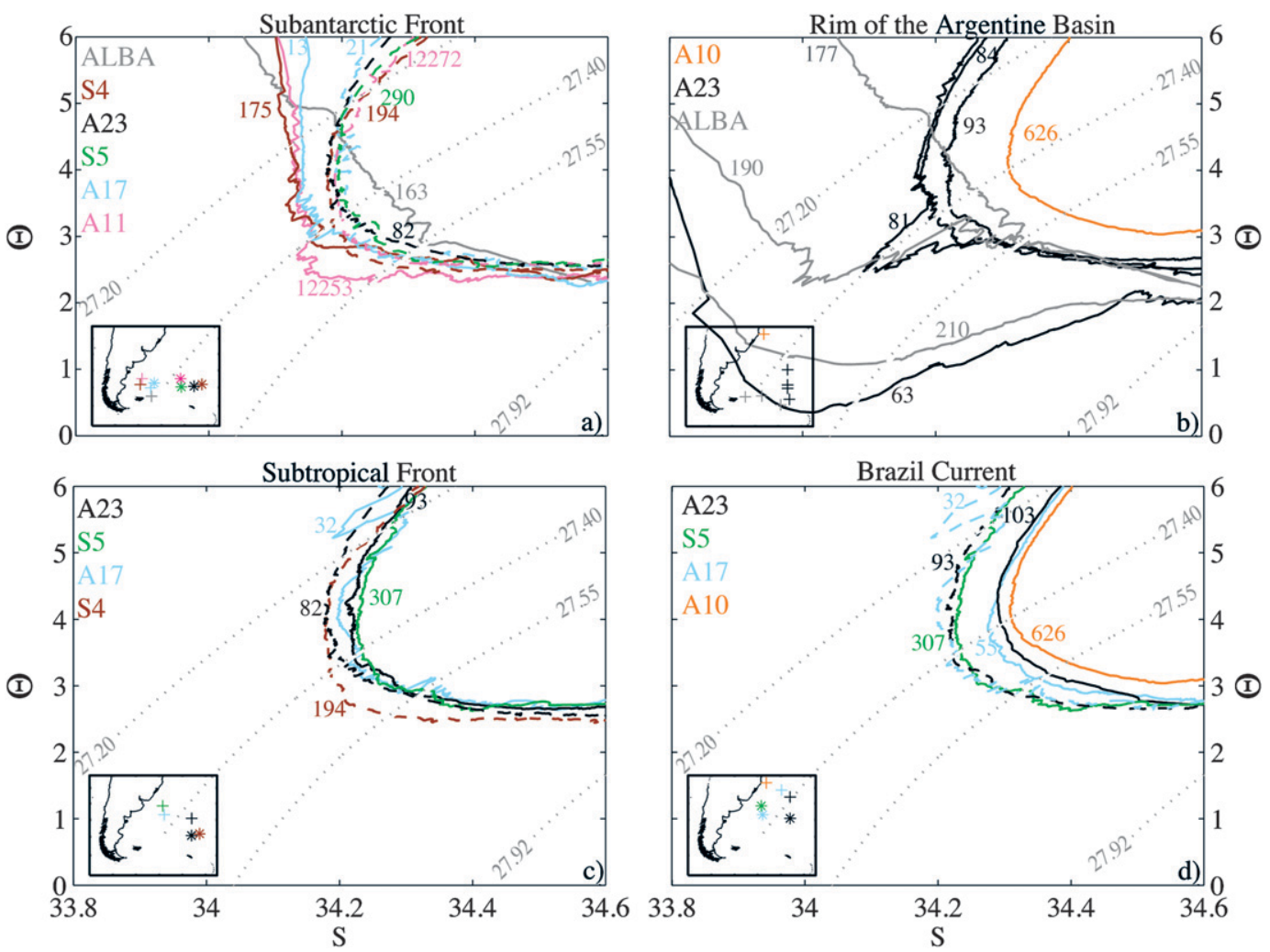

FIG. 3. Thermohaline properties in the SAMW/AAIW density range: (a) properties of SAMW and AAIW along the rim of the BMC; (b) properties of SAMW and AAIW in the MC and its return flow; (c) properties of SAMW and AAIW in the central AB; and (d) difference in properties of AAIW on the northern and southern side of the DF in the AB. The dotted lines are the neutral density boundaries of the main water masses. The station locations corresponding to the profiles plotted are shown in the subpanels. Crosses and stars in the inset maps correspond to the solid lines and dashed lines, respectively.

(GB), cold and fresh winter water $\left(\theta \sim 0.9^{\circ}-1^{\circ} \mathrm{C} ; S \approx 33.9\right)$ is found in the same density range as AAIW (Fig. 3b).

Near the northern edge of the Argentine Basin, warm $\left(\theta \approx 4^{\circ} \mathrm{C}\right)$ and salty $(S \approx 34.32)$ AAIW that has recirculated in the subtropical gyre and mixed with AAIW of Indian origin (Gordon et al. 1992) injected in the Agulhas Retroflection zone, enters the BMC with the BC (Figs. 3b,d; A10 station 626, yellow profile). The subtropical AAIW is significantly modified along isopycnals during its passage through the $\mathrm{BMC}$, cooling to $\theta \approx 3.6^{\circ} \mathrm{C}$ and freshening to $S \approx 34.25$ [Fig. 3d; A23 station 103, South Atlantic Ventilation Experiment [SAVE5 (S5)] station 293, and A17 station 32]. The subtropical AAIW exiting the BMC has thermohaline properties closer to those of AAIW in the confluence's subantarctic zone (Fig. 3c) than those of AAIW of subtropical characteristics (Fig. 3d), suggesting that most of the AAIW in the southern limb of the subtropical gyre is of newly formed origin.

Just east of the BC, on the Santos Plateau (SP) and in the vicinity of the Rio Grande Rise (RGR; Fig. 3d; A17 station 55 and A23 station 103), AAIW is fresher and cooler than in the BC (Fig. 3d; A10 station 626). This may be attributed to local recirculations or northward eddy advection of the subantarctic variety of the water mass. Evidence of recirculation cells in the eastern Argentine Basin and in the central South Atlantic has been given by Defant (1941) and more recently by Núñez Riboni et al. (2005). These recirculation cells can short circuit the northward transport of newly formed AAIW within the subtropical gyre's southern and eastern limbs.

We note that SAMW and AAIW on the Antarctic Large-Scale Box Analysis and the Role of the Scotia Sea (ALBATROSS) section (Figs. 3a,b; ALBATROSS station 163) are warmer and saltier than mode and intermediate waters found on any other sections and in any other locations in the Argentine Basin [Fig. 3a, solid lines; sections A17, A11, and SAVE4 (S4)], seemingly contradicting our previous statement that waters in the SAF warm and salinify in flowing through the BMC. Naveira Garabato et al. (2009) showed that, because of 

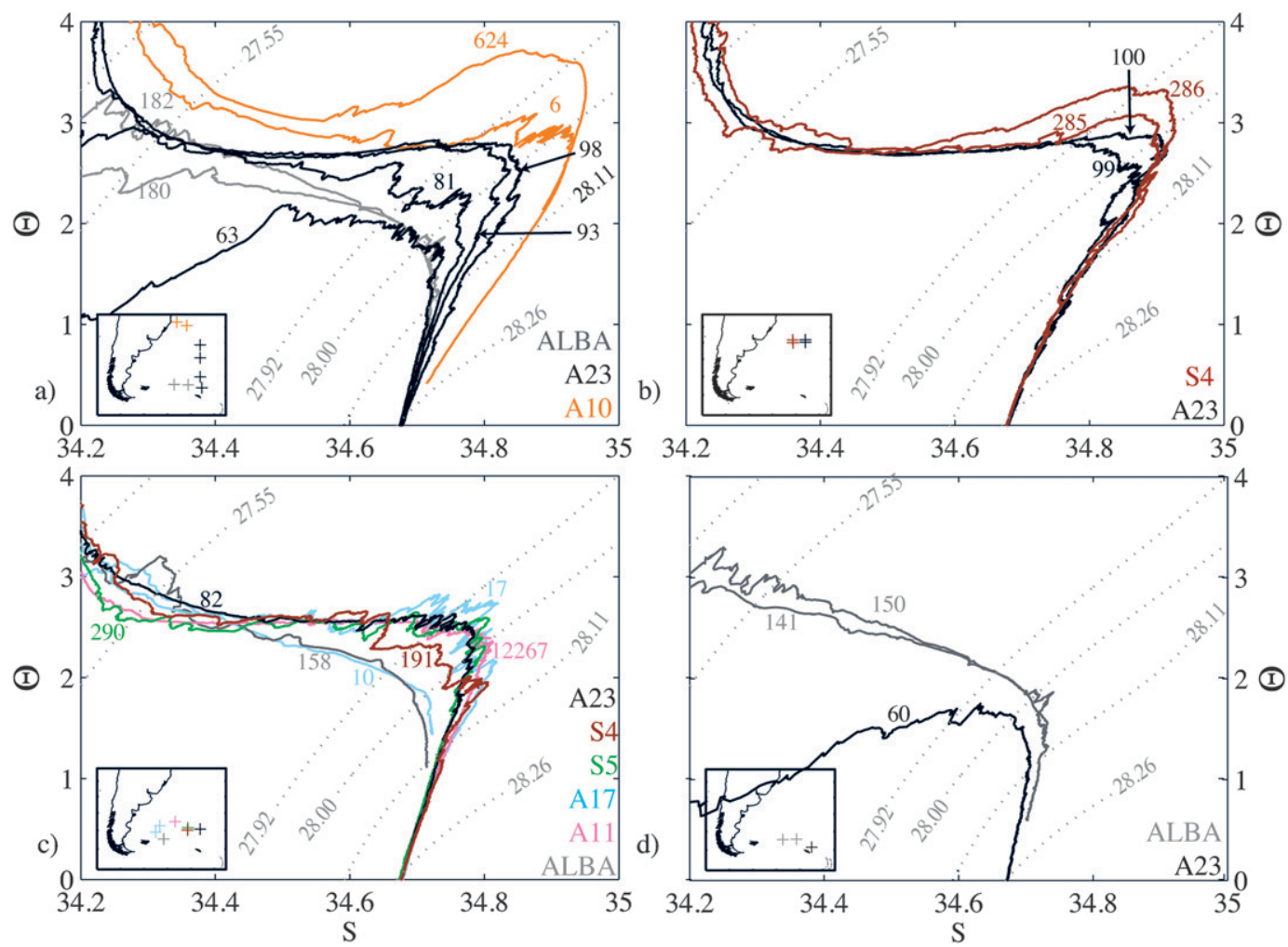

FIG. 4. (a) Properties of NADW along the rim of the BMC; (b) NADW north and south of the DF; (c) CDW properties over the FP; and (d) southward erosion of the NADW salinity maximum along the continental slope and in the MC and its return branch. The dotted lines are the neutral density boundaries of the main water masses. The station locations corresponding to the profiles plotted are shown in the subpanels.

an extreme atmospheric forcing event, the SAMW and AAIW formed in the southwest Atlantic in the winter of 1998/99 (the latter being the year the ALBATROSS section was occupied) were significantly warmer and saltier than at any other time in the last four decades and so should be considered as temporally anomalous in the context of the other sections examined here.

\section{b. Deep water $\left(\gamma^{n}=27.55-28.26 \mathrm{~kg} \mathrm{~m}^{-3}\right)$}

In the NADW/CDW density range, a gradual meridional transition from NADW in the north to CDW in the south is observed (Fig. 4a). In the northern Argentine Basin, two distinct salinity maxima are clearly visible. In the BC (Fig. 4a; A10 station 624), NADW has a salinity of 34.93; east of the BC, over the Santos Plateau (A10 station 6), salinity is lower by 0.02 . The Deep Front (DF), marked by a southward decrease in salinity (by 0.06 ) on the $\gamma_{n}=28.11 \mathrm{~kg} \mathrm{~m}^{-3}$ surface, is the maximum poleward extent of the eastward flow of NADW that has just left the boundary current (Memery et al. 2000). The DF is crossed on the A23 section between stations 99 and 100 and on the SAVE5 section between stations 285 and 286 (Fig. 4b). South of the DF, in the STF region, the salinity maximum is strongly eroded by 0.11 (34.82 on the A23 section, station 93; Fig. 4a).

In the southern Argentine Basin, NADW plays a role in the modification of the CDW of the ACC, as evidenced by the increased interleaving fine structure $(S \approx$ 34.77 at $\gamma_{n}=28.11 \mathrm{~kg} \mathrm{~m}^{-3}$ ) in the return branch of the MC (Fig. 4c; SAVE4 station 191, SAVE5 station 290, A17 station 17, A23 station 82, and A11 station 12267). This branch flows alongside the BC overshoot, staying in contact with NADW for an extended period and facilitating mixing between NADW and CDW. Peterson and Whitworth (1989), Arhan et al. (1999), Wienders et al. (2000), and Heywood and King (2002) also showed evidence of pronounced NADW influence in the CDW in the southern Argentine Basin.

The return branch of the MC appears to act as a boundary to the southward spreading of NADW, because the stations closest to the Falkland Escarpment (Fig. 4c; $S \approx 34.67$ on $\gamma_{n}=28.11 \mathrm{~kg} \mathrm{~m}^{-3}$ at ALBATROSS station 158 and A17 station 10) do not present evidence of NADW influence. Nevertheless, NADW can sporadically be entrained farther south, as shown by ALBATROSS 
station 150 (Fig. 4d) on the western side of the Maurice Ewing Bank (MEB), where evidence of mixing with saltier NADW is visible. At this location, Arhan et al. (2002) identified an anticyclonic recirculation around the Maurice Ewing Bank that entrains NADW across the Falkland Plateau. Colder and fresher CDW that entered the Georgia Basin by circumnavigating South Georgia (SG) rather than overflowing the North Scotia Ridge (Naveira Garabato et al. 2002) is present at station 60 on the A23 section (Fig. 4d). Moreover, Heywood and King (2002) noted that, on A23, the close proximity of the SAF and the PF may facilitate cross-frontal transfer of deep water as shown by the A23 station 63 (Fig. 4a), which exhibits an NADW influence.

\section{c. Water mass modification in the BMC}

Despite the limited spatial extent of the region, the $\mathrm{BMC}$ is thus seen to host drastic water mass modifications as a result of mixing between waters of subantarctic and subtropical origin. AAIW in the subtropical gyre is ventilated by the injection of newly formed AAIW originating in Drake Passage. At the exit of the BMC, the subtropical AAIW has properties closer to those of AAIW in the subantarctic region than in the $\mathrm{BC}$, indicating a locally prominent contribution of subantarctic AAIW to the ventilation of the subtropical thermocline. The NADW salinity maximum is gradually eroded as NADW flows southward, whereas the CDW in the SAF becomes warmer and saltier in the NADW density range, indicating that not all of the NADW leaves the western boundary at the DF but that some continues southward in the Argentine Basin and mixes across the SAF with CDW.

Previous studies have shown evidence of cross-frontal mixing at SAMW/AAIW and NADW/CDW levels in the BMC using various sets of hydrographic and float data (Piola and Georgi 1982; Peterson and Whitworth 1989; Bianchi et al. 1993; Boebel et al. 1999). Here, we show that these water mass modifications are qualitatively consistent from one hydrographic section to another; thus, despite the strong mesoscale variability associated with the BMC, the downstream evolution of thermohaline properties along the BMC is relatively steady (with the exception of the highly anomalous observations of 1999), suggesting that mixing within the confluence largely overwhelms temporal variations in the source waters on the multiannual time scales of relevance to this study. Taking advantage of this relative steadiness in water mass properties, we now construct a box inverse model and arrive at an optimal, self-consistent estimate of the circulation and cross-stream exchanges of heat and salt in the BMC.

\section{Box inverse model}

\section{a. Hydrographic sections}

We construct a box inverse model surrounding the BMC (Fig. 1a) using three nonsynoptic hydrographic sections (ALBATROSS, A23, and A10; Table 1). The southern part of the box, between the Falkland Islands (FI) and South Georgia, is an approximately zonal line of the ALBATROSS cruise (Naveira Garabato et al. 2002). The northern edge of the box, between the Brazilian shelf and the Rio Grande Rise ( $\left.30^{\circ} 4^{\prime} 49^{\prime \prime} \mathrm{S}, 36^{\circ} 15^{\prime} 31^{\prime \prime} \mathrm{W}\right)$, is a segment of the World Ocean Circulation Experiment (WOCE) A10 section. The box is bounded to the west by the South American coast and to the east by a part of the quasi-meridional WOCE A23 section (Heywood and King 2002). Table 1 summarizes the stations used to construct the box as well as the relevant literature describing each of the sections. The stations (Fig. 1a) are numbered anticlockwise from the Falkland Islands (station 1) to the Brazilian coast (station 121). The Rio Grande Rise is a suitable place to join the A10 and A23 sections to reduce errors in lateral volume fluxes stemming from the nonsynopticity of the two sections, because it is shallow $(1000 \mathrm{~m})$ and situated in the low EKE region (Fig. 1a), away from any major current. For simplicity, the A23 and A10 sections are considered as one section, which is labeled as the WOCE section.

The salinity section along the rim of the box (Fig. 5) shows the boundary between two distinct broad oceanographic domains, the subtropical and subantarctic domains. The northern part of the box is characterized by the high-salinity $(S>36)$ surface waters of the subtropical gyre, whereas the southern part of the box is characterized by low-salinity surface waters freshened by sea ice melt $(S<34)$. The most evident frontal region is marked by the plunging of the isohalines at stations 61-66. Here, the PF and the SAF merge near $49^{\circ} \mathrm{S}$ and are almost impossible to separate, as noted by Heywood and King (2002). The SAF and PF are also crossed on the ALBATROSS section. The SAF is located near $53^{\circ} \mathrm{W}$ (stations 9 and 10 ) and reaches down to the sea floor as shown by the tilting of the isopycnals at this longitude. In the Georgia Basin, the steep isopycnals indicate the presence of the $\mathrm{PF}$ at $42^{\circ} \mathrm{W}$ (stations $31-33$ ). Another PF signature, weaker than in the Georgia Basin, has been revealed in lowered ADCP (LADCP) measurements over the Falkland Plateau at $49^{\circ}-50^{\circ} \mathrm{W}$ (Arhan et al. 2002). On the WOCE section, north of the SAF, the low-salinity AAIW is present at about 800 $1000 \mathrm{~m}$ and overrides the salinity maximum of NADW at about $2500 \mathrm{~m}$. At stations 70-74, the section crosses a meander of the STF, denoted by an inflection of the isopycnals (Fig. 5). The BCF, which is defined as the 

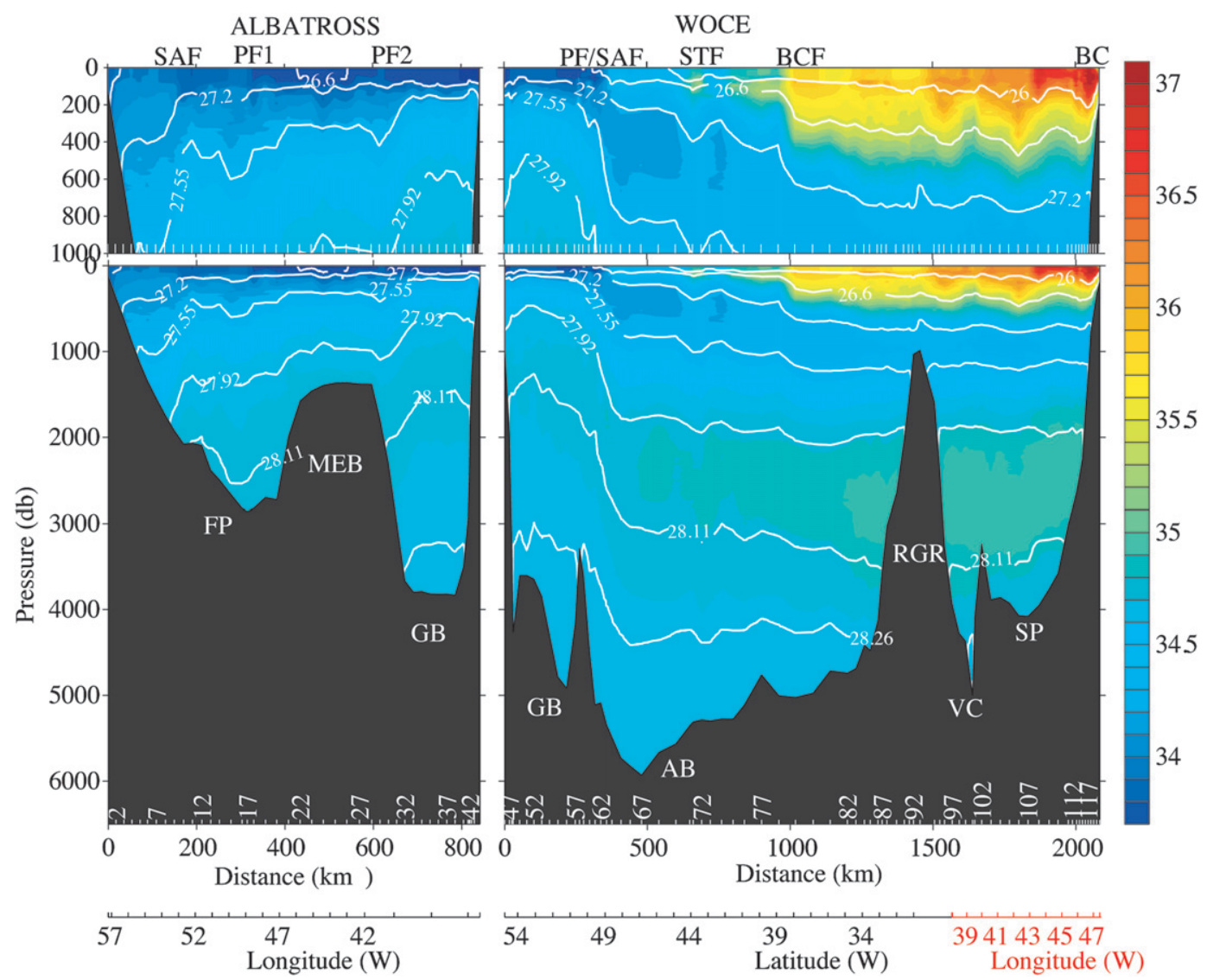

FIG. 5. Salinity section along the rim of the box. Station numbers are shown in white at the bottom of each panel. The white lines represent isopycnal water mass boundaries $\left(\gamma^{n}=26.0,26.6,27.2,27.55,27.92,28.11\right.$, and $\left.28.26 \mathrm{~kg} \mathrm{~m}^{-3}\right)$. Longitudes over the zonal part of WOCE are shown in red, whereas latitudes over the meridional part of WOCE are shown in black.

return flow of the $\mathrm{BC}$, is crossed next, as manifested in the sharp plunging of the isopycnals and isohalines at stations 78-80 (Fig. 5). The BC is marked by a shoaling of the isopycnals along the Brazilian continental shelf in the north of the section (stations 115-121). The reader is referred to the papers cited in Table 1 for further details on the hydrography of the sections used in the inverse model.

\section{b. Box inverse model setup}

Box inverse models (Wunsch 1978) have been widely used in physical oceanography (e.g., McDonagh and King 2005; Sloyan and Rintoul 2000, 2001a,b; Ganachaud 2003b; Gille 1999; Macdonald 1998) because they provide a simple but effective way of estimating the ocean circulation by combining observations (such as hydrographic sections and direct velocity measurements) in a theoretical framework in which conservation of mass and other tracers is enforced. Using thermal wind balance, the geostrophic velocity field (relative to an arbitrary level) across the edges of a box, defined by hydrographic sections and land boundaries, is calculated from the density field, which is derived from the temperature and salinity data.

The box is divided vertically into layers (31 in our case, using neutral density as shown in Table 2) to resolve vertical variations in the lateral transports and diapycnal exchanges. Conservation of mass, heat, and salt (approximated here as volume, potential temperature, and salinity) is imposed (within uncertainties) for each layer and for the full water column, giving 93 equations for our model. This set of equations is used to solve for four different types of unknowns:

- the depth-independent adjustment to the barotropic geostrophic velocity for each station pair (119 unknowns);

- a diapycnal velocity for each property and layer interface $w^{\star}$, representing the net effect of all the diapycnal processes at each interface below the ocean surface, as suggested by Sloyan and Rintoul (2000; 90 unknowns); 
TABLE 2. Neutral density $\left(\mathrm{kg} \mathrm{m}^{-3}\right)$ boundaries of the main water masses used in the inverse model and the corresponding model layer numbers.

\begin{tabular}{lcc}
\hline \hline Water mass & Neutral density limits & Layer No. \\
\hline Surface water & $>26.3$ & $1-4$ \\
STMW & $26.0-26.5$ & $5-7$ \\
SAMW & $26.5-27.2$ & $8-10$ \\
AAIW & $27.2-27.55$ & $11-13$ \\
UCDW & $27.55-27.92$ & $14-17$ \\
NADW & $27.92-28.11$ & $18-23$ \\
LCDW & $28.11-28.26$ & $24-28$ \\
WSDW & $>28.26$ & $29-31$ \\
\hline
\end{tabular}

- a net air-sea heat flux $M_{\theta}$ (31 unknowns) for each of the model layers and a net diapycnal volume flux across each layer interface induced by air-sea interactions $F_{v}$ (30 unknowns); and

- a layer-specific Ekman flux $\bar{C}_{\mathrm{Ek}} \bar{v}_{\mathrm{Ek}} h_{\mathrm{Ek}}$ for each of the properties (96 unknowns), where $\bar{v}_{\mathrm{Ek}}$ is the Ekman velocity, $h_{\mathrm{Ek}}$ represents the depth of the Ekman layer, and $\bar{C}$ is the value of the property at the surface in the outcropping layers.

The conservation equations are discretized over each station pair and each layer and take the form

$$
\begin{gathered}
\sum_{i=1}^{n} \sum_{j=1}^{m}\left[\delta_{i} L_{i} D_{i j}\left(V_{i j}+b_{i}\right) \rho_{i j} C_{i j}+\bar{\rho} \bar{C}^{\mathrm{Ek}} \overline{\boldsymbol{v}}^{\mathrm{Ek}} h_{\mathrm{Ek}}\right] \\
-\left(A \overline{\rho C w_{c}}\right)_{\mathrm{bot}}^{\mathrm{top}}-\left(F_{v}\right)_{\mathrm{bot}}^{\mathrm{top}}-\left[M_{\theta}(j)\right]=0,
\end{gathered}
$$

where $i=1, \ldots, n$ and $j=1, \ldots, m$ are the station pairs and layer numbers, respectively; $D_{i j}$ is the layer thickness for each layer and station pair; $L_{i}$ is the station pair width; $V_{i j}$ is the baroclinic geostrophic velocity at each layer and station pair; $b_{i}$ is the barotropic geostrophic velocity at each station pair; $\delta_{i}$ takes the value +1 or -1 depending on the sign of the transport; and the overbar denotes an average over the layer. An additional constraint is added to the model for full-depth silicate conservation. The potential temperature and salinity equations are formulated in terms of anomalies by subtracting the section mean value from each temperature and salinity data point,

$$
\begin{aligned}
& T_{i j}^{\prime}=T_{i j}-\bar{T} \quad \text { and } \\
& S_{i j}^{\prime}=S_{i j}-\bar{S},
\end{aligned}
$$

where the overbar here denotes the mean property value along the rim of the box. McIntosh and Rintoul (1997) and Ganachaud (2003a) have shown that anomaly equations improve the conditioning of the model matrix by reducing the impact of noisy mass flux divergences on the property flux divergences.

One might wonder if the choice of inverse methods, especially using nonsynoptic data, is sensible in such a highly variable region as the BMC. We argue that the sections used in this study are situated along the relatively quiescent rim of the Argentine Basin, sufficiently far away from the confluence's hub, where the EKE is highest (Fig. 1a). This allows us to estimate the net effect of mesoscale variability on overturning and water mass modifications while minimizing the impact of the variability on the error budget of the inversion. The analysis of thermohaline properties in section 2 confirms that the "signal" of mixing processes in the BMC is considerably larger than the "noise" of temporal variability at the model's bounding sections, such that the properties of the water masses at the exit of the region are relatively constant.

\section{c. Prior estimates of the unknowns and weighting}

\section{1) REFERENCE VELOCITIES}

To guide the model toward an optimal solution, a priori estimates of the unknowns are specified. An initial estimate of the reference velocities is constructed by reference to previously published studies focusing on the sections used in our model (Heywood and King 2002; Naveira Garabato et al. 2003; McDonagh and King 2005). On the ALBATROSS section, we use the initial reference velocities calculated by Naveira Garabato et al. (2003) by performing a least squares fit of geostrophic shear profiles to station pair averages of detided LADCP profiles (see Arhan et al. 2002 for a description of the LADCP data and the referencing procedure).

Across the WOCE section, because of the lack of direct velocity measurements, we tested several level-ofno-motion assumptions so as to obtain the best possible initial estimate of the transport. As far as the DF (station pair 83), the presence of strong full-depth eastward flows associated with the PF, the SAF, and the BCF compels us to reference the geostrophic shear to the deepest common level (DCL) of each station pair and to set the reference velocities to zero. Several authors (Peterson and Whitworth 1989; Arhan et al. 1999; Naveira Garabato et al. 2002) suggested the presence of a westward flow of WSDW crossing the A23 section north of the Northeast Georgia Rise (NGR). At station pair 61, a westward velocity of $0.14 \mathrm{~m} \mathrm{~s}^{-1}$ was found by Arhan et al. (1999), so the prior reference velocity at the DCL was set to that value here.

Heywood and King (2002) interpreted the DF as the center of the subtropical gyre and changed their level of no motion there to $\gamma_{n}=27.92 \mathrm{~kg} \mathrm{~m}^{-3}$, the boundary 
between the eastward-flowing NADW and the westwardflowing Upper CDW (UCDW). We also choose this level of no motion in the DF area. Between the Rio Grande Rise and the Brazilian continental shelf (station pairs 92-119), moored current meter data indicate a northward flow of Lower CDW (LCDW) and a southward flow of NADW (Müller et al. 1998). Therefore, we choose the isopycnal between the two water masses, $\gamma_{n}=$ $28.11 \mathrm{~kg} \mathrm{~m}^{-3}$, as the level of no motion. The geostrophic shear in the BC (station pairs 115-119) is initially referenced to the DCL and the reference velocities subsequently modified so as to reproduce a transport of $\sim 25 \mathrm{~Sv}$, which is consistent with published values (McDonagh and King 2005; Müller et al. 1998). Wherever the isopycnal chosen as the level of no motion is not present, the DCL is used instead.

Transports in bottom triangles are calculated by extrapolating the velocity at the DCL down to the sea floor. In the Vema Channel (VC; stations 98-100), McDonagh et al. (2002) showed that, because of the channel's steep boundaries and the large vertical geostrophic shear, the traditional method of extrapolating geostrophic velocities was not accurate enough and led to an underestimation of the transport through the channel. Hence, at the two deepest station pairs, the bottom triangles are manually adjusted to conserve the shear and to obtain a transport of AABW of $3.5 \mathrm{~Sv}$, corresponding to published estimates (Zemba 1994; Wienders et al. 2000; McDonagh et al. 2002; Heywood and King 2002).

The system of equations and unknowns needs to be weighted correctly to account for the baroclinic variability of the circulation, uncertainties in the prior estimates of the unknowns, and errors associated with various assumptions made in the model. A discussion of our weighting procedure is given in appendix A.

\section{2) DIAPYCNAL VELOCITIES AND AIR-SEA INTERACTIONS}

To initialize the diapycnal velocities, the areaweighted-mean potential temperature and salinity for each layer interface in the box are extracted from the $0.5^{\circ}$-resolution WOCE global hydrographic climatology (Gourestski and Koltermann 2004). This climatology has the advantage of averaging properties along isopycnals rather than isobaric surfaces, thus preventing the formation of spurious water masses (Lozier et al. 1994). The diapycnal velocities across the layer interfaces are initially set to zero and their a priori uncertainties to a large value $\left(10^{-5} \mathrm{~m} \mathrm{~s}^{-1}\right)$, reflecting our lack of prior knowledge of diapycnal transfer processes. McIntosh and Rintoul (1997) showed, by testing inverse modeling techniques in the context of a numerical ocean circulation model, that the inclusion of diapycnal velocities is crucial to obtaining satisfying results, even if the diapycnal fluxes are themselves small, because this improves the conditioning of the model matrix for inversion and decreases the sensitivity of results to data errors.

The mean monthly averaged, nonadjusted net heat flux, net evaporation, and wind stress are extracted from the National Oceanography Centre version 1.1 (NOC1.1) climatology (Josey et al. 1998) to provide an initial estimate of the air-sea fluxes $M_{\theta}$, the water mass transformation induced by air-sea interactions $F_{v}$, and Ekman velocities. The $1 / 4^{\circ}$-resolution monthly averaged sea surface temperature and salinity of the World Ocean Atlas (Boyer et al. 2005) are used to calculate the monthly positions of the outcropping layers and their area. Appendix B details the equations used to calculate air-sea interactions and Ekman transports.

The climatological datasets used here all contain errors, and estimating the combination of all these errors is very difficult. The a priori errors for the air-sea fluxes, Ekman transports, and air-sea-induced diapycnal volume fluxes are set to $80 \%$ of their respective a priori values to crudely account for the large uncertainties in the various datasets.

\section{d. Selecting the preferred solution}

Because of the under determination of the inverse model, the system is solved using singular value decomposition (Wunsch 1996). The rank of the solution (60 out of 97 equations) is selected so that the equation residuals are indistinguishable from zero within a posteriori error bars, whereas the a posteriori values of the unknowns do not depart from the initial values within one a priori standard deviation. Note that a range of ranks close to 60 (50-65) could have been chosen with little impact on the solution. The a posteriori solution, covariance matrices, and errors are calculated in the framework of the Gauss-Markov formulation of the inverse problem (for more details, see Wunsch 1996, p. 184). They are versions of the prior solution and equation covariance matrices updated in accordance with the new information provided by the model equations and include the null space (the part of the solution unresolved by the model equations). The error bars shown henceforth are calculated on the basis of these a posteriori errors.

To assess the robustness of the selected solution, a set of experiments (suppressing temperature and salinity conservation equations, changing the a priori errors in the reference velocities and the layer uncertainties, and suppressing the diapycnal terms) were conducted to assess the sensitivity of the model to its different parameters (Jullion 2008). The impacts of these tests on 
TABLE 3. Summary of the influence on the outputs of the model of the sensitivity tests performed to assess the stability of the model.

\begin{tabular}{|c|c|c|c|c|c|c|}
\hline & $\begin{array}{l}\mathrm{SAF}+\mathrm{PF} \\
\text { in }(\mathrm{Sv})\end{array}$ & $\begin{array}{c}\mathrm{SAF}+\mathrm{PF} \\
\text { out }(\mathrm{Sv})\end{array}$ & STF (Sv) & $\mathrm{BC}(\mathrm{Sv})$ & $\begin{array}{l}\text { Air-sea heat } \\
\text { flux }\left(\mathrm{W} \mathrm{m}^{-2}\right)\end{array}$ & $\begin{array}{l}\text { rms vol layer } \\
\text { residual }(\mathrm{Sv})\end{array}$ \\
\hline Selected solution & 130 & 106 & 20 & 26 & 23 & 4.6 \\
\hline Volume conservation only & 134 & 99 & 15 & 26 & - & 19.6 \\
\hline Hyperbolic row errors & 83 & 90 & 19 & 26 & 28 & 5.2 \\
\hline 21 layers & 130 & 106 & 20 & 26 & 23 & 4.6 \\
\hline Error reference velocities $=0.04 \mathrm{~m} \mathrm{~s}^{-1}$ & 133 & 106 & 20 & 26 & 25 & 3.5 \\
\hline No bottom triangle & 131 & 108 & 20 & 20 & 26 & 5.0 \\
\hline No diapycnal velocities & 38 & 148 & 15 & 13 & - & 0.6 \\
\hline Error diapycnal velocities $=10^{-1} \mathrm{~m} \mathrm{~s}^{-1}$ & 134 & 99 & 16 & 26 & 25 & 20.0 \\
\hline
\end{tabular}

a few basic outputs of the model are summarized in Table 3. The solutions of the tests were of poorer quality than the selected solution, as denoted by larger layer residuals and inconsistencies in the transport of the ACC and the subtropical gyre. Nonetheless, the inverse model results are generally robust to changes, with the exception of the exclusion of the diapycnal terms. The importance of the inclusion of these terms is an expected result, as already discussed in section $3 \mathrm{c}$.

\section{Inverse model results}

\section{a. Geostrophic velocity and lateral volume transport}

The changes in the reference velocities made by the inversion (Figs. 6a,b) have an rms value of $1.9 \mathrm{~mm} \mathrm{~s}^{-1}$. The largest changes (about $-6 \mathrm{~mm} \mathrm{~s}^{-1}$ ) occur against the slope of the Falkland Islands (station pair 2), where the fast-flowing SAF jet is found, and in the $\mathrm{BC}$, along the Brazilian continental shelf (station pair 117). Changes on the order of $-4 \mathrm{~mm} \mathrm{~s}^{-1}$ also occur near the Rio Grande Rise (station pairs 90 and 91) and in the WOCE section, where the core of the $\mathrm{SAF} / \mathrm{PF}$ is found (station pairs 45-54). Between the Rio Grande Rise and the Brazilian shelf, the inversion increases the reference velocities by $\sim 2 \mathrm{~mm} \mathrm{~s}^{-1}$. In the rest of the box, the changes are smaller than $2 \mathrm{~mm} \mathrm{~s}^{-1}$. In the Argentine Basin, the a posteriori velocities at the sea bed are now westward (null a priori). The diapycnal velocities, having a median magnitude of $1 \times 10^{-7} \mathrm{~m} \mathrm{~s}^{-1}$, are generally small, and the changes made by the inversion to the prior air-sea heat flux, Ekman terms, and air-sea-induced diapycnal volume fluxes are commonly up to $5 \%$ of their original values.

For the selected solution, the geostrophic (barotropic + baroclinic) velocities and the cumulative volume transport are calculated (Fig. 6). The individual layer and depthintegrated volume transport associated with each front (Tables 4, 5) are computed. The volume transports diagnosed by the inversion are close to previously published estimates [Naveira Garabato et al. (2003) and Arhan et al. (2002) for the ALBATROSS section, Heywood and
King (2002) for A23, and McDonagh et al. (2002) and McDonagh and King (2005) for A10]. The range of error bars in Tables 4 and 5 is large, from $5 \%$ to $100 \%$ of the solution, depending on the layer.

The model indicates that the independent a priori transport estimates used to set up the model have a high degree of mutual consistency (within error bars). Building on this positive result, we next examine the solution for evidence of cross-frontal exchanges in the BMC. By comparing the structure of the different frontal currents flowing in and out of the $\mathrm{BMC}$ region, one can infer the modifications undergone by these frontal systems during their passage through the BMC.

\section{b. Diapycnal fluxes, Ekman transports, and air-sea fluxes}

The interior diapycnal fluxes, air-sea heat fluxes, Ekman transports, and air-sea-induced diapycnal volume fluxes calculated by our inverse model (not shown) are not distinguishable from zero for the entire water column because of the large a priori and a posteriori error bars. Our results suggest that the modification of the density and thermohaline structures of the ACC and the subtropical gyre occurs mainly by isopycnal mixing between subtropical and subantarctic waters, rather than by diapycnal mixing or air-sea interaction. The net airsea heat flux within the box calculated by the model is close to the initial climatological estimate $\left[O(20) \mathrm{W} \mathrm{m}^{-2}\right.$ before and after the inversion], indicating that the NOC1.1 climatology is reasonably consistent with the regional hydrography and the conservation constraints imposed by the model. Moreover, the inclusion of airsea heat fluxes, Ekman transports, and air-sea-induced diapycnal volume fluxes makes little difference to the inversion; the results with or without their inclusion are indistinguishable within uncertainties.

\section{c. Cross-stream overturning at the ACC-subtropical gyre boundary}

In flowing through the BMC region, the SAF undergoes significant modifications in terms of its vertical 

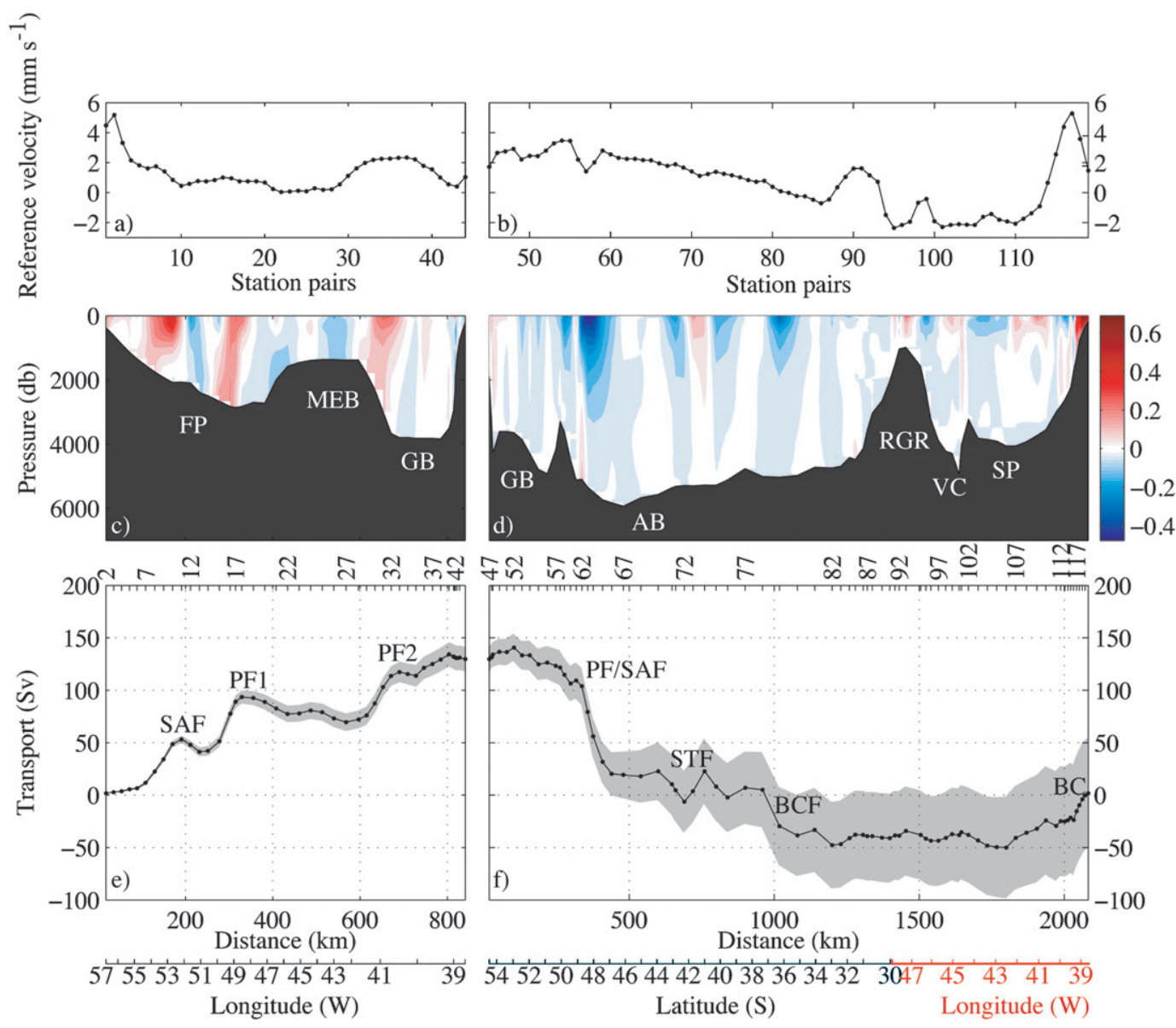

FIG. 6. A priori reference velocities minus a posteriori reference velocities on (a) the ALBATROSS section and (b) the WOCE section in $\mathrm{mm} \mathrm{s}^{-1}$. A posteriori geostrophic velocities across (c) the ALBATROSS section and (d) the WOCE section in $\mathrm{m} \mathrm{s}^{-1}$. Total cumulative volume transport across (e) the ALBATROSS section and (f) the WOCE section in Sv. A positive geostrophic velocity-transport is directed into the box. Bathymetry as in Fig. 5 .

structure (Fig. 7). The total volume transport of the SAF increases in the BMC (Fig. 7a), transporting more $\mathrm{UCDW}(+9 \pm 4 \mathrm{~Sv})$ and LCDW $(+15 \pm 3 \mathrm{~Sv})$ across the WOCE section (Table 4$)$ than across the ALBATROSS section but conveying less SAMW and AAIW (-12 \pm $1 \mathrm{~Sv}$ and $-4 \pm 2 \mathrm{~Sv}$, respectively). The larger volume of $\mathrm{CDW}$ in the return branch of the SAF can be explained by a transfer of water from the PF branches turning eastward at the Falkland Escarpment. Peterson and Stramma (1991) and Arhan et al. (1999) showed that the SAF in the Argentine Basin transports CDW too dense to overflow the Falkland Plateau with the SAF (Fig. 7a) and that therefore these waters of PF origin are injected in the SAF by a deep boundary current flowing westward against the Falkland Escarpment. The decrease in the volume transports of SAMW and AAIW following the SAF is indicative of a transfer of mode and intermediate waters from the SAF toward the subtropical region in the BMC. Moreover, the SAF transports lighter mode water across the WOCE section (Fig. 7a), suggesting that either some SAMW is transformed into lighter water in the confluence (a possibility admitted by the uncertain diapycnal fluxes in the solution) or that mode water of subtropical origin is transferred to the SAF.

The difference in the volume transport between the $\mathrm{BC}(31 \pm 5 \mathrm{~Sv}$, including the DWBC) and the BCF $(44 \pm 15 \mathrm{~Sv}$ ) is $13 \pm 16 \mathrm{~Sv}$ (Fig. 7c; Table 5): that is, not significantly different from zero. The STF (Fig. 7d), situated between the SAF and the BCF, carries mostly SAMW, AAIW, and UCDW that have been exported from the SAF in the BMC region. Our diagnosed AAIW flow in the STF $(7 \pm 1 \mathrm{~Sv})$ agrees well with the estimate of Núñez Riboni et al. (2005), who found 8.5 $\pm 3.5 \mathrm{~Sv}$ of AAIW flowing east with the STF. However, our total estimate of the AAIW flow between the STF and the BCF $(17 \pm 1.5 \mathrm{~Sv})$ is about twice the estimate of Núñez 
TABLE 4. Transport estimates associated with the ACC fronts at their entrance and exit of the BMC (Sv). Positive transports are directed into the box. PF1 and PF2 correspond to the two branches of the PF over the FP and in the GB, respectively. The error bars are calculated from the a posteriori errors on the geostrophic velocities.

\begin{tabular}{|c|c|c|c|c|c|c|c|}
\hline & \multicolumn{7}{|c|}{$\mathrm{ACC}$} \\
\hline & \multicolumn{4}{|c|}{ Inflow } & \multicolumn{3}{|c|}{ Outflow } \\
\hline & SAF & PF1 & PF2 & SACCF & SAF & PF1 & SACCF \\
\hline SW & 0 & 0 & 0 & 0 & 0 & 0 & 0 \\
\hline STMW & 0 & 0 & 0 & 0 & $-2 \pm 0.5$ & $-0.4 \pm 0.5$ & 0 \\
\hline SAMW & $15 \pm 1$ & $3 \pm 0.5$ & $3 \pm 0.5$ & $1 \pm 0.1$ & $-3 \pm 1$ & $-3 \pm 0.5$ & $1 \pm 0.5$ \\
\hline AAIW & $19 \pm 1$ & $6 \pm 1$ & $5 \pm 1$ & $1 \pm 0.1$ & $-15 \pm 2$ & $-11 \pm 1$ & $-1 \pm 0.5$ \\
\hline UCDW & $15 \pm 1$ & $13 \pm 4$ & $21 \pm 2$ & $5 \pm 1$ & $-24 \pm 4$ & $-25 \pm 2$ & $-5 \pm 1$ \\
\hline LCDW & $-0.2 \pm 0.1$ & $6 \pm 2$ & $24 \pm 5$ & $5 \pm 2$ & $-16 \pm 3$ & $-10 \pm 4$ & $-8 \pm 2$ \\
\hline WSDW & 0 & 0 & $2 \pm 1$ & $\sim 0$ & $-2 \pm 2$ & $5 \pm 2$ & $-1 \pm 1$ \\
\hline Total & $49 \pm 3$ & $27 \pm 8$ & $55 \pm 8$ & $12 \pm 2$ & $-62 \pm 7$ & $-44 \pm 7$ & $16 \pm 4$ \\
\hline
\end{tabular}

Riboni et al. A probable explanation of this discrepancy is that part of the AAIW leaving the BMC may recirculate west of the Mid-Atlantic Ridge.

\section{d. Subduction of mode and intermediate waters into the subtropical gyre}

Because of the confluence of the $\mathrm{MC}$ and the $\mathrm{BC}$, the southwest Atlantic is a region where water mass exchanges between the subtropical gyre and the ACC are likely to occur, as shown by Campos et al. (1995) and Schouten and Matano (2006). Our inverse model quantifies a transfer of $16 \pm 4 \mathrm{~Sv}$ of SAMW/AAIW from the SAF into the STF, in the southern limb of the subtropical gyre. The similarity between the AAIW properties in the STF/BCF and in the SAF (Fig. 3) qualitatively reinforces our hypothesis that most of the water at the southern edge of the subtropical gyre is of subantarctic origin, although substantially modified by isopycnal mixing with warm and saline subtropical waters from the BC (see section 2c).

In the BMC, SAMW and AAIW sink along isopycnals under the lighter surface water of the subtropical gyre and are isolated from atmospheric influence. Therefore, one can interpret the $16 \pm 4 \mathrm{~Sv}$ of cross-frontal transfer of SAMW and AAIW found in our model as a subduction rate. Our results suggest that the BMC hosts a substantial fraction of the $21.9 \mathrm{~Sv}$ of SAMW/AAIW subduction into the South Atlantic subtropical gyre calculated by Donners et al. (2005) in a global ocean circulation model. From climatological data, Karstensen and Quadfasel (2002) showed that, in the density range of SAMW and AAIW, subduction in the South Atlantic was dominated by lateral transfer in the BMC, in qualitative agreement with our findings. The transfer of SAMW and AAIW from the ACC to the subtropical gyre is also suggested by the ALACE float observations of Davis et al. (1996), in which two floats deployed in
Drake Passage were seen to become trapped in the confluence and subsequently drift eastward with the STF, toward the Mid-Atlantic Ridge.

We conclude that the BMC plays a prominent role in the subduction of subantarctic mode and intermediate waters into the pycnocline of the subtropical gyre. The mechanisms responsible for this subduction cannot be directly assessed in a box inversion, because the model only provides explicit transport estimates across the sides of the box and between layers. However, given the lack of shallow topographic barriers in the region and the location of SAMW and AAIW largely below typical Ekman layer depths, it is reasonable to argue that eddy advection is likely to be the dominant contributor to subduction of SAMW/AAIW into the subtropical gyre. Tanaka and Hasumi (2008) recently highlighted the role of eddies in the subduction of water in the BMC in the context of an eddy-permitting numerical model. From our inversion, it is only possible to speculate about the fate of the mode and intermediate waters subducted in the BMC. It is probable that a part follows the STF into

TABLE 5. Total and water mass transport (in Sv) of the BC, the DWBC, the BCF, and the STF. The error bars are calculated as in Table 4.

\begin{tabular}{lcccr}
\hline \hline & \multicolumn{3}{c}{ BC } \\
\cline { 2 - 4 } & BC & DWBC & BCF & STF \\
\hline SW & $8 \pm 0.5$ & $-2 \pm 0.5$ & $-3 \pm 0.5$ & $-2 \pm 1$ \\
STMW & $4 \pm 1$ & $-1 \pm 0.5$ & $-4 \pm 0.5$ & $-1 \pm 1$ \\
SAMW & $7 \pm 2$ & $\sim 0 \pm 0.5$ & $-12 \pm 1$ & $-5 \pm 1$ \\
AAIW & $4 \pm 1$ & $1 \pm 1$ & $-10 \pm 2$ & $-7 \pm 1$ \\
UCDW & $3 \pm 1$ & $4 \pm 1$ & $-8 \pm 3$ & $-5 \pm 1$ \\
NADW & 0 & $3 \pm 1.5$ & $-5 \pm 3$ & $-1 \pm 2$ \\
LCDW & 0 & 0 & $-1 \pm 2.9$ & $0 \pm 2$ \\
WSDW & 0 & 0 & $-\sim 0 \pm 2$ & $-1 \pm 2$ \\
Total & $26 \pm 5$ & $6 \pm 2$ & $-44 \pm 14$ & $-20 \pm 8$ \\
\hline
\end{tabular}



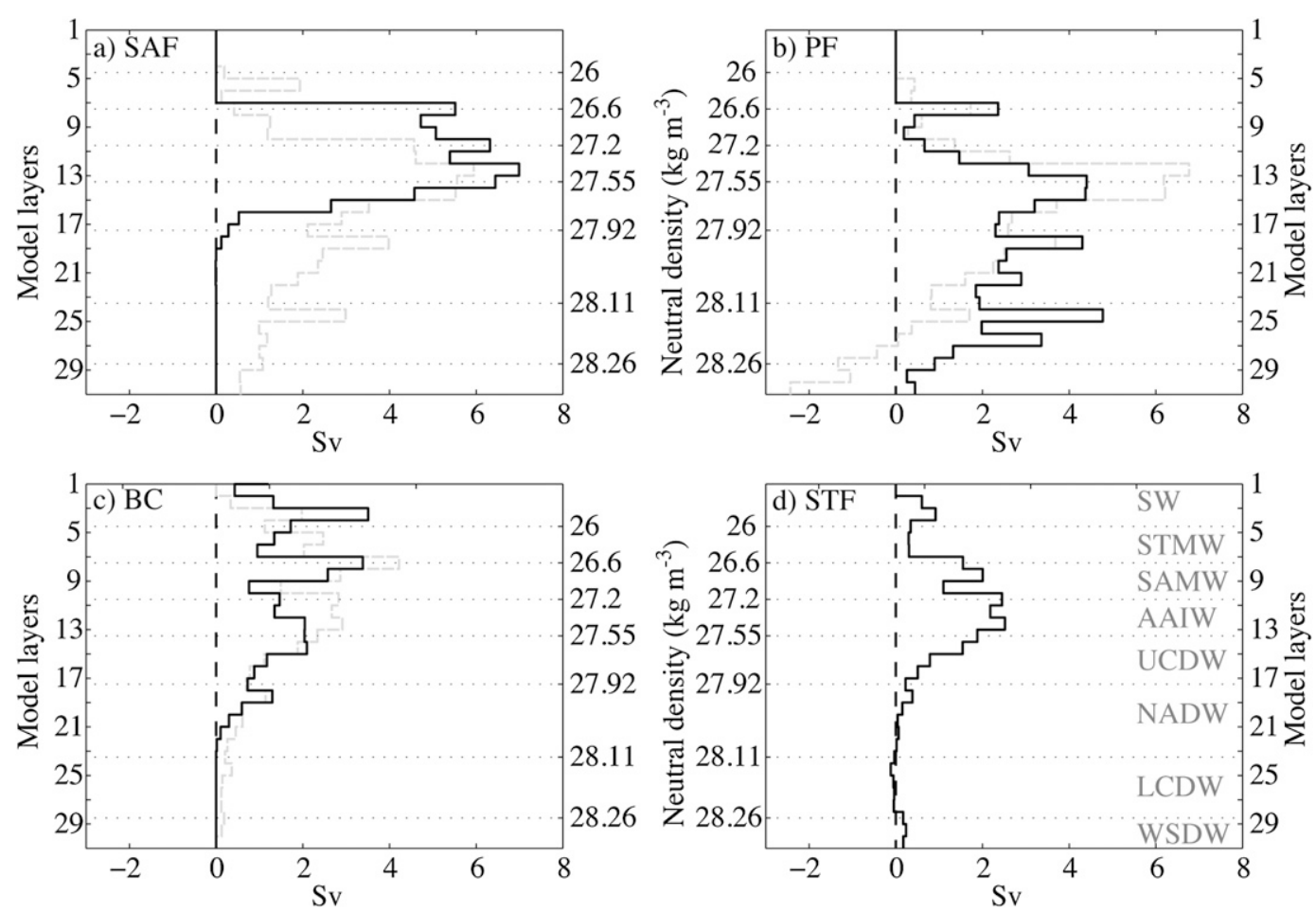

FIG. 7. Vertical structure of the (a) SAF, (b) PF, (c) BC, and (d) STF flowing in (black) and out (gray) of the box. Neutral density water mass boundaries are shown as dotted lines and water masses are labeled in (d). Note that both transports have the same sign to facilitate the comparison. The vertical dashed line marks the zero transport.

the Indian Ocean, whereas another fraction circulates in the South Atlantic subtropical gyre and eventually crosses the equator. The latter option is suggested by the numerical simulations of England and Garçon (1994), which indicated that the westward branch of the subtropical gyre (the Benguela Current) was made up of approximately three parts of South Atlantic water and one part of Indian Ocean water.

\section{e. Cross-stream exchanges of heat and salt in the $B M C$}

We now analyze the cross-stream exchanges of heat and salt in the BMC by calculating the volume-transportweighted heat and salt divergences (Fig. 8) in the model layers (meaning that the volume divergence in each layer is removed). We find sizeable cross-stream exchanges of heat and salt between the subtropical gyre, which cools and freshens, and the ACC, which warms and becomes saltier, as the two current systems flow through the BMC region. The heat and salt divergences associated with cooling and freshening of the subtropical gyre in the $\mathrm{BMC}$ are found to be $-0.09 \mathrm{PW}$ and $-5.9 \times 10^{12} \mathrm{~kg} \mathrm{~s}^{-1}$ (Fig. 8a). In the SAF, the model diagnoses convergences of heat and salt of $0.06 \mathrm{PW}$ and $2.4 \times 10^{12} \mathrm{~kg} \mathrm{~s}^{-1}$ between the inflow and the outflow (Fig. 8b). The negative fluxes in the denser AAIW layers (layers 12 and 13), caused by the anomalous character of the temperature and salinity of the AAIW on the ALBATROSS section, reduce the total net heat and salt gain of the SAF in the BMC. We estimate the impact of these anomalous AAIW properties on the cross-stream heat and salt fluxes by artificially setting the AAIW temperature and salinity on the ALBATROSS section to the properties measured on other sections in the southern Argentine Ba$\sin$ (i.e., a potential temperature of $3.0^{\circ} \mathrm{C}$ and a salinity of 34.18; see section 2), whereas assuming that the flow through the ALBATROSS transect remains unchanged. We find an increase in the total heat and salt convergences in the SAF on the order of $30 \%-40 \%(0.09 \mathrm{PW}$ and $\left.3.1 \times 10^{12} \mathrm{~kg} \mathrm{~s}^{-1}\right)$. This calculation shows that the heat and salt convergences found in our model solution are a lower-bound value to the heat and salt gained by the SAF in the BMC and that the typical heat and salt convergence in the ACC is likely greater. In the PF region (Fig. 8c), the model also reveals an increase in the heat and salinity transport ( $0.03 \mathrm{PW}$ and $\left.1.2 \times 10^{12} \mathrm{~kg} \mathrm{~s}^{-1}\right)$, indicating that the cross-stream heat and salt transfer into the ACC is not confined only to the SAF region directly in contact with the subtropical gyre but also extends to the core of the ACC farther south. 

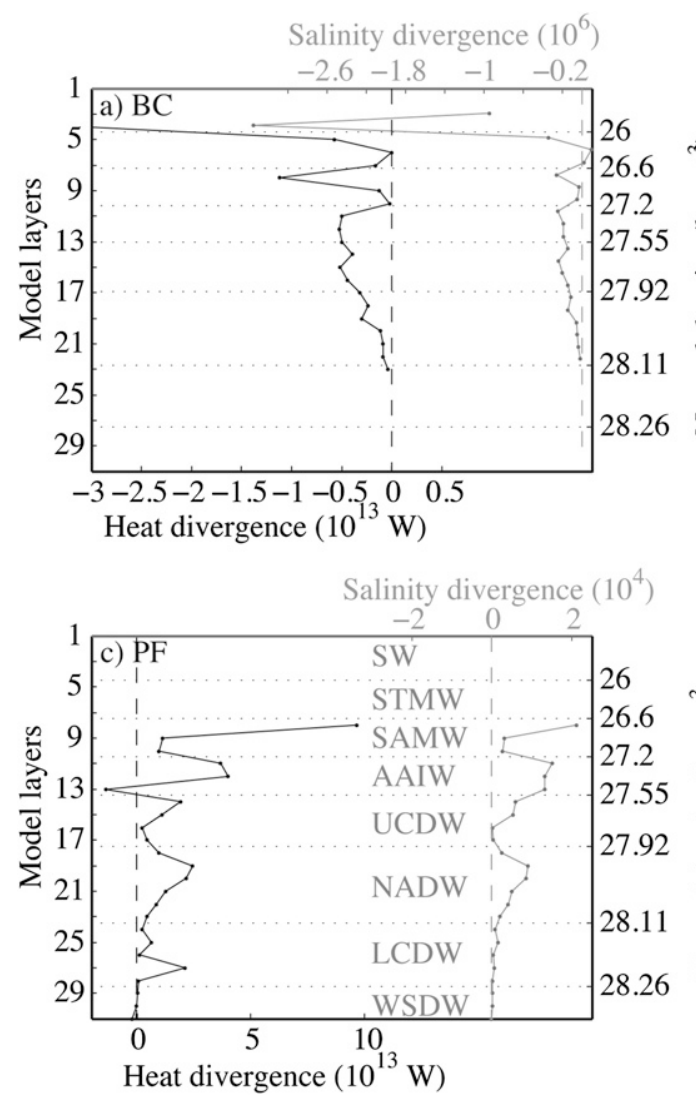

\section{f. Contribution of the BMC to the heat and salt exchanges between the ACC and the South Atlantic subtropical gyre}

Cross-frontal exchanges in the BMC were estimated by Bianchi et al. (1993) from the medium-scale fine structure (10-100 m wavelength) in a set of high-resolution CTD sections focused on the hub of the confluence. In the upper ocean, they calculated a cross-frontal heat flux of $\sim 10^{-2 \circ} \mathrm{C} \mathrm{m} \mathrm{s}^{-1}$ and a salt flux of $10^{-3} \mathrm{~m} \mathrm{~s}^{-1}$. In the NADW layers, they found both the heat and salt fluxes to be on the order of $10^{-3 \circ} \mathrm{C} \mathrm{m} \mathrm{s}^{-1}$. We can crudely estimate the heat and salt divergences implied by Bianchi et al.'s results by scaling their cross-frontal heat and salt transfers by the climatological alongfront area of the relevant layer in the BMC, specific heat capacity, and in situ density. The climatological length of the SAF in the box is $\sim 4000 \mathrm{~km}$ (Orsi et al. 1995), the average thickness of the SAMW/AAIW layer is $\sim 700 \mathrm{~m}$, and the average thickness of the NADW/CDW layer is $\sim 1000 \mathrm{~m}$. We find that the cross-frontal fluxes of heat and salt in the SAMW/AAIW layer, scaled by the climatological lengths of the SAF, are on the order of $10^{-3 \circ} \mathrm{C} \mathrm{m} \mathrm{s}^{-1}$ and $10^{-4} \mathrm{~m} \mathrm{~s}^{-1}$, respectively, and that, in the NADW layer,

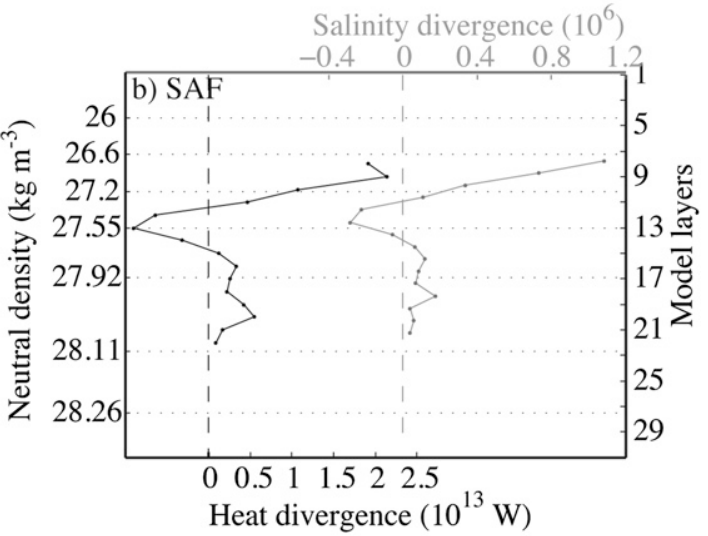

FIG. 8. (a) BC, (b) SAF, and (c) PF layer heat (black) and salt (gray) divergences in the BMC. The contribution of the layer volume divergences has been removed. Black dashed lines represent the water mass limits. Horizontal dotted lines represent the water mass limits and the vertical dashed lines mark the zero divergence. A positive value means a heat (salt) gain in the layer, whereas a negative value means a heat (salt) loss in the layer. the scaled heat and salt fluxes are on the order of $10^{-3}$. Thus, our estimates agree with Bianchi et al.'s calculations within one order of magnitude, which is as much as one may reasonably expect, given the assumption of spatial homogeneity in mixing intensity implicit in the comparison and the crudeness of the scaling. This broad agreement suggests that the cross-frontal mixing rates found by Bianchi et al. (1993) over a relatively small region in the heart of the BMC (their Fig. 2) may hold over a wide swath of the confluence.

Our inverse model diagnoses substantial cross-stream exchanges of heat and salt between the subtropical gyre and the ACC, mostly occurring in the SAMW/AAIW and NADW density ranges and translating in potential temperature and salinity increases in the SAMW/AAIW and CDW of the subantarctic domain (Figs. 3, 4). The heat and salt injected southward across the BMC are advected eastward with the ACC. The former will ultimately contribute to balancing the air-sea heat loss south of the PF. Sun and Watts (2002) estimated a total ACCintegrated poleward heat flux of $0.14 \mathrm{PW}$ across $56^{\circ} \mathrm{S}$ and $0.08 \mathrm{PW}$ across $60^{\circ} \mathrm{S}$ and reached the qualitative conclusion that the lateral exchanges in the BMC and the Agulhas Retroflection region were the main sources of 
heat and salt to the ACC. Our results quantitatively endorse this proposition by showing that the southward heat injection across the BMC contributes up to half of the circumpolar cross-ACC heat flux estimated by Sun and Watts (2002). Like our model, Sun and Watts (2002) also ruled out air-sea interactions in the BMC as the primary source of heat to the ACC in the region.

\section{Conclusions}

The analysis of a collection of high-quality hydrographic observations in the BMC region reveals drastic thermohaline modifications in the frontal systems of the ACC and the subtropical gyre flowing through the confluence. In the SAF, the SAMW, AAIW, and CDW become warmer (saltier) by $0.4^{\circ}(0.08), 0.3^{\circ}(0.02)$, and $0.6^{\circ} \mathrm{C}(0.1)$, respectively. In the subtropical gyre, AAIW and NADW cool (freshen) by $0.4^{\circ}(0.07)$ and $0.7^{\circ} \mathrm{C}$ (0.11), respectively.

To investigate these water mass modifications and the associated cross-confluence overturning, the large-scale circulation of the BMC is estimated by combining three nonsynoptic sections in the framework of a box inverse model. The calculated lateral transports associated with the frontal systems converging in the BMC are generally consistent with previous qualitative and quantitative views of the circulation in the southwest Atlantic, indicating a high degree of mutual consistency between the independent estimates of the regional circulation in the literature.

The inverse model results show a significant modification of the vertical structure of the frontal jets crossing the BMC region. In the intermediate layers, SAMW $(12 \pm 1 \mathrm{~Sv})$ and AAIW $(4 \pm 2 \mathrm{~Sv})$ from the SAF are transferred toward the STF. The newly subducted waters become warmer and saltier, primarily by eddyinduced isopycnal mixing with recirculated subtropical SAMW and AAIW. Our estimates of subduction of SAMW and AAIW suggest that the BMC is responsible for a large fraction (on the order of $50 \%$ ) of the total subduction rate in the South Atlantic as estimated by previous studies.

Cross-stream heat and salt exchanges across the $\mathrm{BMC}$ are estimated to result in the warming and salinification (cooling and freshening) of the ACC (subtropical gyre) by $0.06 \mathrm{PW}(-0.09 \mathrm{PW})$ and $2.4 \times$ $10^{12} \mathrm{~kg} \mathrm{~s}^{-1}\left(-5.9 \times 10^{12} \mathrm{~kg} \mathrm{~s}^{-1}\right)$. Our results support the role of the BMC as a major source of heat to the ACC, with a contribution estimated to be up to half of the circumpolar cross-ACC poleward heat flux estimated by Sun and Watts (2002).

Our inverse model diagnostics highlight the BMC's prominent role in the overturning, subduction, and heat and salt transports across the boundary between the
ACC and the subtropical gyre of the South Atlantic. In future work, we intend to investigate some of the key physical processes (such as eddy-induced mixing and the stirring properties of the Zapiola recirculation) likely underpinning cross-confluence exchanges.

Acknowledgments. LJ thanks UEA for his Ph.D. studentship. ACNG was supported by a NERC Advanced Research Fellowship (NE/C517633/1). We are grateful to Michel Arhan and Catherine Lagadec for providing the SAVE data. Elaine McDonagh kindly contributed her reference velocities for the A10 section. We thank Simon Josey for his assistance with the NOC climatology. Finally, we thank Lynne Talley and two anonymous reviewers whose comments helped to significantly improve the quality of this paper.

\section{APPENDIX A}

\section{Model Weighting Procedure}

Equation (1) needs to be weighted to account for uncertainties in the conservation statements and prior estimates of unknowns. If the uncertainty of a given equation/unknown is large, the importance or weight in the system should be reduced. We introduce an a priori estimate of equation and unknown uncertainties to guide the model toward a realistic solution. We need to weight both the equations (rows) and the unknowns (columns). For the row weighting, the inverse of the square root of the equation uncertainty covariance matrix $\mathbf{W}_{r}$, which is usually taken as a diagonal matrix in the absence of any prior knowledge of its structure (Wunsch 1996), is used. For the column weighting, the inverse of the square root of the a priori solution uncertainty covariance matrix $\mathbf{W}_{c}$, which is usually taken as diagonal for the same reason, is used (Wunsch 1996). Thus, the definitions of $\mathbf{W}_{r}$ and $\mathbf{W}_{c}$ are

$$
\mathbf{W}_{c}=\left(\begin{array}{ccc}
\frac{1}{\sqrt{\varepsilon_{c 1}}} & \cdots & 0 \\
\vdots & \ddots & \vdots \\
0 & \cdots & \frac{1}{\sqrt{\varepsilon_{c n}}}
\end{array}\right) \mathbf{W}_{r}=\left(\begin{array}{ccc}
\frac{1}{\sqrt{\varepsilon_{r 1}}} & \cdots & 0 \\
\vdots & \ddots & \vdots \\
0 & \cdots & \frac{1}{\sqrt{\varepsilon_{r m}}}
\end{array}\right),
$$

where $\varepsilon_{r}$ and $\varepsilon_{c}$ are the a priori uncertainties of the reference velocities and the a priori uncertainties of the conservation equations, respectively.

The error budget of inverse models has been shown to be dominated by noise in the observations, baroclinic 
TABLE A1. Estimation of the errors on transport (Sv) at midlatitudes (Ganachaud 2003b). The uncertainties in the volume transport of each layer of our model have been set using these estimates.

\begin{tabular}{ll}
\hline \hline \multicolumn{1}{c}{ Layer } & Error \\
\hline Top layers & \pm 2 \\
Bottom layers & \pm 0.1 \\
Depth integrated & \pm 5 \\
\hline
\end{tabular}

variability (especially in the case of nonsynoptic data), and the incomplete physics of a model based on thermal wind (McIntosh and Rintoul 1997; Ganachaud 2003b). Using global circulation models to assess the different source of errors and their importance, Ganachaud (2003a) found that errors resulting from baroclinic variability were larger in the upper ocean than in the deep ocean. Hence, he recommended that uncertainties in the deep layer volume conservation should be reduced compared with the uncertainties in the upper layer equations and in the depth-integrated equation (see Table A1). Giving a higher uncertainty to the upper layers is satisfactory as long as the residuals after inversion in these layers are indistinguishable from the uncertainties. Ganachaud (2003a) found that the measurement noise is dominated by internal waves, which can lead to a $\pm 3 \mathrm{~Sv}$ volumetransport uncertainty at midlatitudes. For this study, the equations are weighted by the inverse of the square root of their a priori uncertainties. For the weighting of the conservation statements, little information about the baroclinic variability in the region is available; therefore, Ganachaud (2003a)'s rule of thumb is used to weight the layer-specific and full-depth volume conservation equations (see Table A1). Because of the nonsynopticity of the sections in a region of high variability, the uncertainties in the surface layers are conservatively set to be twice the values recommended by Ganachaud (2003b). A sensitivity test where the uncertainties in the upper layers are increased to $8 \mathrm{~Sv}$ (instead of $4 \mathrm{~Sv}$ ) was also made, and the changes in the solution were found to be negligible. The a priori uncertainties in the conservation of properties other than volume are estimated as double the product of the a priori uncertainties in volume conservation and the standard deviation or the mean (whichever is the largest) of property variations within the relevant layer (Naveira Garabato et al. 2003; Table A2). The choice between the mean and standard deviation is motivated by the presence of very small values of standard deviation resulting in very large errors. Bottom triangles and the geostrophic assumption have a smaller influence. Moreover, the layer weights are normalized by the area of the layers, because surface layers are usually smaller than the deep layers.
TABLE A2. A priori errors in the volume conservation equations for the model layers, layer mean, and standard deviation of potential temperature $\theta$ and salinity used to weight the conservation equations.

\begin{tabular}{|c|c|c|c|}
\hline Layer & Error (Sv) & $\begin{array}{c}\text { Mean } \pm \text { std } \\
\operatorname{dev} \theta\left({ }^{\circ} \mathrm{C}\right)\end{array}$ & $\begin{array}{l}\text { Mean } \pm \\
\text { std dev } S\end{array}$ \\
\hline 1 & 4 & $24.043 \pm 1.299$ & $36.398 \pm 0.478$ \\
\hline 2 & 4 & $23.129 \pm 1.306$ & $36.321 \pm 0.482$ \\
\hline 3 & 4 & $21.339 \pm 1.563$ & $36.109 \pm 0.503$ \\
\hline 4 & 4 & $18.586 \pm 1.753$ & $35.845 \pm 0.562$ \\
\hline 5 & 4 & $16.144 \pm 1.836$ & $35.568 \pm 0.505$ \\
\hline 6 & 4 & $14.218 \pm 1.876$ & $35.311 \pm 0.469$ \\
\hline 7 & 3 & $12.613 \pm 2.490$ & $35.083 \pm 0.544$ \\
\hline 8 & 3 & $8.494 \pm 3.283$ & $35.427 \pm 0.615$ \\
\hline 9 & 3 & $6.026 \pm 2.290$ & $35.231 \pm 0.372$ \\
\hline 10 & 3 & $4.622 \pm 1.766$ & $34.146 \pm 0.257$ \\
\hline 11 & 3 & $3.857 \pm 1.467$ & $34.129 \pm 0.195$ \\
\hline 12 & 3 & $3.132 \pm 1.223$ & $34.142 \pm 0.148$ \\
\hline 13 & 3 & $2.639 \pm 1.003$ & $34.220 \pm 0.114$ \\
\hline 14 & 1 & $2.488 \pm 0.639$ & $34.366 \pm 0.074$ \\
\hline 15 & 1 & $2.476 \pm 0.404$ & $34.522 \pm 0.056$ \\
\hline 16 & 1 & $2.479 \pm 0.458$ & $34.634 \pm 0.074$ \\
\hline 17 & 1 & $2.450 \pm 0.485$ & $34.696 \pm 0.082$ \\
\hline 18 & 1 & $2.420 \pm 0.512$ & $34.738 \pm 0.088$ \\
\hline 19 & 1 & $2.338 \pm 0.532$ & $34.776 \pm 0.096$ \\
\hline 20 & 1 & $2.168 \pm 0.514$ & $34.794 \pm 0.095$ \\
\hline 21 & 1 & $1.963 \pm 0.472$ & $34.793 \pm 0.089$ \\
\hline 22 & 1 & $1.746 \pm 0.424$ & $34.787 \pm 0.080$ \\
\hline 23 & 0.5 & $1.499 \pm 0.337$ & $34.770 \pm 0.067$ \\
\hline 24 & 0.5 & $1.307 \pm 0.279$ & $34.757 \pm 0.057$ \\
\hline 25 & 0.5 & $0.991 \pm 0.207$ & $34.736 \pm 0.041$ \\
\hline 26 & 0.5 & $0.660 \pm 0.135$ & $34.715 \pm 0.025$ \\
\hline 27 & 0.5 & $0.432 \pm 0.098$ & $34.701 \pm 0.017$ \\
\hline 28 & 0.5 & $0.206 \pm 0.085$ & $34.688 \pm 0.011$ \\
\hline 29 & 0.5 & $0.303 \pm 0.019$ & $34.675 \pm 0.003$ \\
\hline 30 & 0.5 & $-0.142 \pm 0.021$ & $34.670 \pm 0.002$ \\
\hline 31 & 0.5 & $-0.224 \pm 0.041$ & $34.666 \pm 0.003$ \\
\hline Full depth & 5 & $5.938 \pm 0.8457$ & $34.852 \pm 0.207$ \\
\hline
\end{tabular}

The uncertainties in the reference velocities can be determined using, for example, current meters to indicate the variability of the geostrophic velocity. Ganachaud (2003b) evaluated the variability of the reference velocity to be between 0.5 and $1 \mathrm{~cm} \mathrm{~s}^{-1}$, and he suggested the use of a deep reference level to minimize the error in the deep transport created by an artificial high velocity at the bottom. The reference velocities are weighted by the square root of their uncertainties (Table A3).

TABLE A3. Summary of the uncertainty in reference velocities of each station pair along the rim of the box.

\begin{tabular}{lccc}
\hline \hline & ALBATROSS & \multicolumn{2}{c}{ WOCE } \\
\hline Station pairs & $1: 44$ & $45: 92$ & $93: 119$ \\
Uncertainty $\left(\mathrm{m} \mathrm{s}^{-1}\right)$ & $2 \times 10^{-2}$ & $2 \times 10^{-2}$ & $4 \times 10^{-2}$ \\
\hline
\end{tabular}




\section{APPENDIX B}

\section{Air-Sea Flux Formulation}

The air-sea flux formulation used in this paper is a slightly modified and corrected version of Naveira Garabato et al. (2003) and Sloyan and Rintoul (2000), which they derived from the work of Tziperman and Speer (1994). The net air-sea fluxes of mass $M_{v}$ and heat $M_{\theta}$ into outcropping layers, as well as the atmosphere and the diapycnal volume flux induced by air-sea interaction $F_{v}$, are calculated by integrating the air-sea freshwater flux $Q$ and the air-sea net heat flux $H$ :

$$
\begin{aligned}
M_{\theta} & =\int_{T} d t \int_{A} \frac{H}{C_{p} \rho} d A, \\
M_{v} & =\int_{T} d t \int_{A} \frac{-Q}{d} A, \text { and } \\
F_{v} & =\int_{T} d t \int_{A_{\Delta}}\left[\frac{1}{\Delta \rho}\left(\frac{\alpha H}{C_{p}}-\rho \beta Q S\right)\right] d A,
\end{aligned}
$$

where $\Delta \rho$ is the potential density interval centered at $\rho$ over which the flux is calculated; $C_{p}$ is the specific heat capacity of the ocean; $\alpha$ and $\beta$ are the thermal expansion and haline contraction coefficients, respectively; $A_{\Delta}$ is the outcropping area of the density interval $\Delta \rho$; and $A$ is the outcropping area of a layer of mean potential density $\rho$. Here, $F_{v}$ is the diapycnal volume flux across a layer interface (positive toward lighter density) arising from changes in buoyancy induced by net heat and freshwater exchanges between the ocean and the atmosphere.

The $F_{v}$ and $M_{\Theta}$ terms are weighted by the square root of the prior uncertainty. Note that the net volume gain $M_{v}$ is far smaller than the uncertainties resulting from the baroclinic variability in the upper ocean and is therefore neglected (Ganachaud 2003a; Naveira Garabato et al. 2003).

\section{REFERENCES}

Arhan, M., K. J. Heywood, and B. A. King, 1999: The deep waters from the Southern Ocean at the entry to the Argentine Basin. Deep-Sea Res., 46, 475-499.

- A. C. Naveira-Garabato, K. J. Heywood, and D. P. Stevens, 2002: The Antarctic Circumpolar Current between the Falkland Islands and South Georgia. J. Phys. Oceanogr., 32, 1914-1931.

Bianchi, A. A., C. F. Giulivi, and A. R. Piola, 1993: Mixing in the Brazil/Malvinas Confluence. Deep-Sea Res. I, 40,1345-1348.

— A. R. Piola, and G. J. Collino, 2001: Evidence of doublediffusion in the Brazil-Malvinas Confluence. Deep-Sea Res. I, 49, 41-52.

Boebel, O., C. Schmid, G. Podestá, and W. Zenk, 1999: Intermediate water in the Brazil-Malvinas Confluence Zone: A Lagrangian view. J. Geophys. Res., 104 (C9), 21 063-21 082.
Boyer, T., S. Levitus, H. Garcia, R. A. Locarnini, C. Stephens, and J. Antonov, 2005: Objective analyses of annual, seasonal and monthly temperature and salinity for the World Ocean on a $0.25^{\circ}$ grid. Int. J. Climatol., 25, 931-945.

Campos, E., J. Miller, T. Müller, and R. Peterson, 1995: Physical oceanography of the southwest Atlantic Ocean. Oceanography, 8, 87-91.

Davis, R., P. Killworth, and J. Blundell, 1996: Comparison of Autonomous Lagrangian Circulation Explorer and fine resolution Antarctic model results in the South Atlantic. J. Geophys. Res., 101 (C1), 855-884.

Defant, A., 1941: Quantitative Untersuchungen zur Statik und Dynamik des Atlantischen Ozeans. Wiss. Ergeb. Dtsch. Atl. Exped. Meteor (Mainz), 6, 191-260.

Dewar, B., 1998: Topography and barotropic transport control by bottom friction. J. Mar. Res., 56, 295-328.

Donners, J., S. S. Drijfhout, and W. Hazeleger, 2005: Water mass transformation and subduction in the South Atlantic. J. Phys. Oceanogr., 35, 1841-1860.

England, M., and V. Garçon, 1994: South Atlantic circulation in a World Ocean model. Ann. Geophys., 12, 812-825.

Fetter, A. F. H., and R. P. Matano, 2008: On the origins of the variability of the Malvinas Current in a global, eddy-permitting numerical simulation. J. Geophys. Res., 113, C11018, doi:10.1029/ 2008JC004875.

Fu, L. L., 2007: Interaction of mesoscale variability with large-scale waves in the Argentine Basin. J. Phys. Oceanogr., 37, 787-793. , B. Chang, and B. Qiu, 2001: 25-day period large-scale oscillations in the Argentine Basin revealed by the TOPEX/Poseidon altimeter. J. Phys. Oceanogr., 31, 506-517.

Ganachaud, A., 2003a: Error budget of inverse box models: The North Atlantic. J. Atmos. Oceanic Technol., 20, 1641-1655.

_, $2003 \mathrm{~b}$ : Large-scale mass transports, water mass formation, and diffusivities estimated from World Ocean Circulation Experiment (WOCE) hydrographic data. J. Geophys. Res., 108, 3213, doi:10.1029/2002JC001565.

Garnier, E., J. Verron, and B. Barnier, 2003: Variability of the South Atlantic upper ocean circulation: A data assimilation experiment with 5 years of TOPEX/POSEIDON altimeter observations. Int. J. Remote Sens., 24, 911-934.

Garzoli, S. L., and Z. Garaffo, 1989: Transports, frontal motion and eddies at the Brazil-Malvinas Confluence. Deep-Sea Res., 36, 681-703.

_ and C. Giulivi, 1994: What forces the variability of the southwestern Atlantic boundary currents? Deep-Sea Res., 41, 1527-1550.

Gille, S. T., 1999: Mass, heat and salt transport in the southeastern Pacific: A Circumpolar Current inverse model. J. Geophys. Res., 104 (C3), 5191-5209.

Goni, G. J., and I. Wainer, 2001: Investigation of the Brazil Current Front variability from altimeter data. J. Geophys. Res., 106, 31 117-31 128.

Gordon, A. L., 1989: Brazil-Malvinas Confluence-1984. Deep-Sea Res. I, 36, 359-384.

- R. F. Weiss, W. M. Smethie Jr., and M. J. Warner, 1992: Thermocline and intermediate water communication between the South Atlantic and Indian Ocean. J. Geophys. Res., 97, 7223-7240.

Gourestski, V. V., and K. P. Koltermann, 2004: WOCE Global Hydrographic climatology. Berichte des Bundesamtes für Seeschifffahrt und Hydrographie Tech. Rep. 35, 55 pp.

Heywood, K. J., and B. A. King, 2002: Water masses and baroclinic transports in the South Atlantic and Southern Oceans. J. Mar. Res., 60, 639-676. 
Jackett, D., and T. McDougall, 1997: A neutral density variable for the world's oceans. J. Phys. Oceanogr., 27, 237-263.

Josey, S. A., E. C. Kent, and P. K. Taylor, 1998: The Southampton Oceanographic Center (SOC) ocean-atmosphere heat, momentum and freshwater fluxes atlas. Southampton Oceanographic Centre Rep. 6, 30 pp.

Jullion, L., 2008: Water mass modification in the southwestern Atlantic. Ph.D. thesis, University of East Anglia, 243 pp.

Karstensen, J., and D. Quadfasel, 2002: Formation of Southern Hemisphere thermocline waters: Water mass conversion and subduction. J. Phys. Oceanogr., 32, 3020-3038.

Lozier, M., M. McCartney, and W. Owens, 1994: Anomalous anomalies in averaged hydrographic data. J. Phys. Oceanogr., 24, 2624-2638.

Maamaatuaiahutapu, K., V. Garcon, C. Provost, M. Boulahdid, and A. P. Osiroff, 1992: Brazil-Malvinas confluence: Water mass composition. J. Geophys. Res., 97 (C6), 9493-9505.

Macdonald, A., 1998: The global oceanic circulation: A hydrographic estimate and regional analysis. Prog. Oceanogr., 41, 281-382.

Marshall, D., 1997: Subduction of water masses in an eddying ocean. J. Mar. Res., 55, 201-222.

Marshall, J., E. Shuckburgh, H. Jones, and C. Hill, 2006: Estimates and implications of surface eddy diffusivity in the Southern Ocean derived from tracer transport. J. Phys. Oceanogr., 36, 1806-1821.

Matano, R., 1993: On the separation of the Brazil Current from the coast. J. Phys. Oceanogr., 23, 79-90.

McDonagh, E. L., and B. A. King, 2005: Oceanic fluxes in the South Atlantic. J. Phys. Oceanogr., 35, 109-122.

—, M. Arhan, and K. J. Heywood, 2002: On the circulation of bottom water in the region of the Vema Channel. Deep-Sea Res. I, 49, 1119-1139.

McIntosh, P. C., and S. R. Rintoul, 1997: Do box inverse models work? J. Phys. Oceanogr., 27, 291-308.

Memery, L., M. Arhan, X. A. Alvarez-Salgado, M.-J. Messias, H. Mercier, C. G. Castro, and A. F. Rios, 2000: The water masses along the western boundary of the south and equatorial Atlantic. Prog. Oceanogr., 47, 69-98.

Müller, T. J., Y. Ikeda, N. Zangenberg, and L. V. Nonato, 1998: Direct measurements of western boundary currents off Brazil between $20^{\circ} \mathrm{S}$ and $28^{\circ} \mathrm{S}$. J. Geophys. Res., 103, 5429-5437.

Naveira Garabato, A. C., D. P. Stevens, and K. J. Heywood, 2002: Modification and pathways of Southern Ocean deep waters in the Scotia Sea. Deep-Sea Res. I, 49, 681-705.

,$- \ldots$, and — 2003: Water mass conversion, fluxes, and mixing in the Scotia Sea diagnosed by an inverse model. J. Phys. Oceanogr., 33, 2565-2587.

- , L. Jullion, D. Stevens, K. Heywood, and B. King, 2009: Variability of Subantarctic Mode Water and Antarctic Intermediate Water in Drake Passage during the late-twentieth and early-twenty-first centuries. J. Climate, 22, 3661-3688.

Núñez Riboni, I., O. Boebel, M. Ollitrault, Y. You, P. Richardson, and R. Davis, 2005: Lagrangian circulation of Antarctic Intermediate Water in the subtropical South Atlantic. Deep-Sea Res. II, 52, 545-564.

Olson, D. B., G. P. Podestá, R. H. Evans, and O. B. Brown, 1988: Temporal variations in the separation of the Brazil and Malvinas Currents. Deep-Sea Res., 35, 1971-1990.

Orsi, A. H., T. Whitworth, and W. D. Nowlin, 1995: On the meridional extent and fronts of the Antarctic Circumpolar Current. Deep-Sea Res. I, 42, 641-673.

Peterson, R. G., and T. Whitworth, 1989: The Subantarctic and Polar Fronts in relation to deep water masses through the southwestern Atlantic. J. Geophys. Res., 94 (C8), 10 81710838 .

and L. Stramma, 1991: Upper-level circulation in the South Atlantic. Prog. Oceanogr., 26, 1-73.

Piola, A. R., and D. T. Georgi, 1982: Circumpolar properties of Antarctic Intermediate Water and Subantarctic Mode Water. Deep-Sea Res., 29, 687-711.

Provost, C., V. Garçon, and L. Medina Falcon, 1996: Hydrographic conditions in the surface layers over the slope-open ocean transition area near the Brazil-Malvinas Confluence during austral summer 1990. Cont. Shelf Res., 16, 215-235.

, C. Escoffier, K. Maamaatuaiahutapu, A. Kartavtseff, and V. Garçon, 1999: Subtropical mode waters in the South Atlantic. J. Geophys. Res., 104, 21 033-21 049.

Reid, J. L., W. D. Nowlin Jr., and W. C. Patzert, 1977: On the characteristics and circulation of the southwestern Atlantic Ocean. J. Phys. Oceanogr., 7, 62-91.

Saraceno, M., C. Provost, A. R. Piola, J. Bava, and A. Gagliardini, 2004: Brazil Malvinas Frontal System as seen from 9 years of Advanced Very High Resolution Radiometer data. J. Geophys. Res., 109, C05027, doi:10.1029/2003JC002127.

Saunders, P. M., and B. A. King, 1995a: Bottom currents derived from a shipboard ADCP on WOCE cruise A11 in the South Atlantic. J. Phys. Oceanogr., 25, 329-347.

$\longrightarrow$, and 1995b: Oceanic fluxes on the WOCE A11 section. J. Phys. Oceanogr., 25, 1942-1958.

Schouten, M. W., and R. P. Matano, 2006: Formation and pathways of intermediate water in the Parallel Ocean Circulation Model's Southern Ocean. J. Geophys. Res., 111, C06015, doi:10.1029/ $2004 \mathrm{JC} 002357$.

Siedler, G., T. Müller, R. Onken, M. Arhan, and H. Mercier, 1996: The zonal WOCE sections in the South Atlantic. The South Atlantic: Present and Past Circulation, G. Wefer et al., Eds., Springer-Verlag, 105-120.

SIO, 1992: Chemical, physical and CTD data reports, Leg 4, 7 December 1988-15 December 1989; Leg 5, 23 January 19898 March 1989; R/V Melville. Scripps Institution of Oceanography Save Data Rep., 729 pp.

Sloyan, B. M., and S. R. Rintoul, 2000: Estimates of area-averaged diapycnal fluxes from basin-scale budgets. J. Phys. Oceanogr., 30, 2320-2349.

, and - 2001a: Circulation, renewal and modification of Antarctic mode and intermediate water. J. Phys. Oceanogr., 31, 1005-1031.

_, and — 2001b: The Southern Ocean limb of the global deep overturning circulation. J. Phys. Oceanogr., 31, 143-173.

Smith, W. H. F., and D. T. Sandwell, 1997: Global sea floor topography from satellite altimetry and ship depth soundings. Science, 277, 1956-1962.

Spadone, A., and C. Provost, 2009: Variations in the Malvinas Current volume transport since 1992. J. Geophys. Res., 114, C02002, doi:10.1029/2008JC004882.

Sun, C., and D. R. Watts, 2002: Heat flux carried by the Antarctic Circumpolar Current mean flow. J. Geophys. Res., 107, 3119, doi:10.1029/2001JC001187.

Talley, L. D., 1996: Antarctic Intermediate Water in the South Atlantic. The South Atlantic: Present and Past Circulation, G. G. Wefer, W. H. Berger, and D. Webb, Eds., Springer-Verlag, 219-238.

Tanaka, Y., and H. Hasumi, 2008: Injection of Antarctic Intermediate Water into the Atlantic subtropical gyre in an eddy resolving ocean model. Geophys. Res Lett., 35, L11601, doi:10.1029/ 2007GL032915. 
Tsuchiya, M., L. Talley, and M. McCartney, 1994: Water mass distributions in the western South Atlantic; A section from South Georgia Island $\left(54^{\circ} \mathrm{S}\right)$ northward across the equator. J. Mar. Res., 52, 55-81.

Tziperman, E., and K. Speer, 1994: A study of water mass transformation in the Mediterranean Sea: Analysis of climatological data and a simple three-box model. Dyn. Atmos. Oceans, 21, 53-82.

Vivier, F., and C. Provost, 1999: Direct velocity measurements in the Malvinas current. J. Geophys. Res., 104 (C9), 21 083-21 103.

Wainer, I., P. Gent, and P. Goni, 2000: Annual cycle of the BrazilMalvinas Confluence region in the National Center for Atmospheric Research climate system model. J. Geophys. Res., 105, 26 167-26 177.

Weijer, W., F. Vivier, S. Gille, and H. A. Dijkstra, 2008a: Multiple oscillatory modes of the Argentine Basin. Part I: Statistical analysis. J. Phys. Oceanogr., 37, 2855-2868.
,,--- , and,$- 2008 \mathrm{~b}$ : Multiple oscillatory modes of the Argentine Basin. Part II: The spectral origin of basin modes. J. Phys. Oceanogr., 37, 2869-2881.

Wienders, N., M. Arhan, and H. Mercier, 2000: Circulation at the western boundary of the south and equatorial Atlantic: Exchanges with the ocean interior. J. Mar. Res., 58, 1007-1039.

Wilson, H., and N. Rees, 2000: Classification of mesocale features in the Brazil-Falkland Current confluence zone. Prog. Oceanogr., 45, 415-426.

Wunsch, C., 1978: The North Atlantic general circulation west of $50^{\circ} \mathrm{W}$ determined by inverse methods. Rev. Geophys. Space Phys., 16, 583-620.

- 1996: The Ocean Inverse Circulation Inverse Problem. Cambridge University Press, 442 pp.

Zemba, J. C., 1994: The structure and transport of the Brazil Current between $26^{\circ}$ and $32^{\circ} \mathrm{S}$. Ph.D. thesis, Woods Hole Oceanographic Institution, $160 \mathrm{pp}$. 